\title{
Selected Aspects of Camel Immune System and Immune Responses
}

\author{
Saeed Y. Al Ramadan ${ }^{*}$, Kazem T. Al-Mohammed Salem², Ibrahim H. Alshubaith ${ }^{3}$, \\ Ahmed M. Al-Ali' ${ }^{4}$, Salah Abohelaika ${ }^{5}$, Mohammed S. Moqbel' ${ }^{1}$, Ahmed M. Alluwaimi6 \\ ${ }^{1}$ Department of Anatomy, College of Veterinary Medicine, King Faisal University, Al-Ahsaa, Saudi Arabia \\ ${ }^{2}$ Animal Resources Management, Ministry of Environment, Water and Agriculture Al-Ahsaa, Saudi Arabia \\ ${ }^{3}$ Environmental Health Department, Al-Ahsaa Municipality, Al-Ahsa, Saudi Arabia \\ ${ }^{4}$ Central Biotechnology Laboratory, Veterinary Teaching Hospital, College of Veterinary Medicine, King Faisal University, \\ Al-Ahsaa, Saudi Arabia \\ ${ }^{5}$ Clinical Pharmacology Department, Qatif Central Hospital, Ministry of Health, Saudi Arabia \\ ${ }^{6}$ Department of Microbiology and Parasitology, College of Veterinary Medicine, King Faisal University, Al-Ahsaa, Saudi Arabia \\ Email: ^salramadan@kfu.edu.sa, kazemts1983@hotmail.com, ibsubaith@gmail.com, \\ aalali@kfu.edu.sa, sabohelaika@moh.gov.sa, alluwaimi@kfu.edu.sa
}

How to cite this paper: Al Ramadan, S.Y. Al-Mohammed Salem, K.T., Alshubaith, I.H., Al-Ali, A.M., Abohelaika, S., Moqbel, M.S. and Alluwaimi, A.M. (2021) Selected Aspects of Camel Immune System and Immune Responses. Open Journal of Veterinary Medicine, 11, 177-211. https://doi.org/10.4236/ojvm.2021.116013

Received: April 14, 2021

Accepted: June 15, 2021

Published: June 18, 2021

Copyright ( 2021 by author(s) and Scientific Research Publishing Inc. This work is licensed under the Creative Commons Attribution International License (CC BY 4.0).

http://creativecommons.org/licenses/by/4.0/

\section{(c) (i) Open Access}

\begin{abstract}
The camel economy is of considerable importance for arid countries. In the last decade, studies about camel immune system and immune responses have recorded increasing interest. However, drawing a comprehensive picture of the camel immune system remains far from reached. A major part of this review is to cover the studies of the primary and secondary immune organs and the markers of the camel immune cells and certain lymphoid tissues. At the same time, immune responses to different diseases and the nature of effective immunity were included, with an emphasis on the most important zoonotic diseases in camels such as MERS CoV; brucellosis. New findings on the diversity mechanisms of camel immunoglobulin genes were addressed. However, detail of the mechanism of MHC-restricted cellular immunity and the mechanism of B lymphocyte activation in camels await further attention. Interestingly, the gross and the histological structure of the lymphoid tissues of the camel's thymus, tonsils, and peyer's patches have indicated significant differences from other animals in terms of structure and function. The most peculiar CD expression, such as LPAM-I, MAdCAM-1 and CX3CR1, in certain camel cells and tissues refers to possible extraordinary mechanisms of immune hemostasis in camel in comparison to other ruminants. The widely applied immunodiagnostic techniques to control camel diseases and to assist in improving the camel resistance were considered. Extensive studies of the camel immune system were greatly hampered by lack of specific reagents to camel markers and low funds in the field of camel immunology.
\end{abstract}




\section{Keywords}

Camel, CX3CR1, Heavy Chain Antibody, MERS-CoV, Peyer's Patches

\section{Introduction}

In the Qur'an, the camel is a miracle of God, distinct from other animals mentioned in the holy book: "Do (these unbelievers) not observe the camels: how they were created?" (Surah al Ghashiya, Verse 17). Moreover, camel forms an integral part of the culture and agriculture of many people around the world [1]. The camel population was estimated at 35 million heads worldwide [2], of which $89 \%$ are dromedary camels (Camelus dromedarius) and $11 \%$ are Bactrian (Camelus bactrianus and Camelus ferus) [3]. The Camelidae family is divided into two tribes, the new world camel (Lamini) and the old-world camel (Camelini). Within the Camelini, there are two domesticated species-the twohumped Bactrian camel (Camelus bactrianus) and the single-humped dromedary camel (Camelus dromedarius) - in addition to the critically endangered two-humped wild Bactrian camel (Camelus ferus), which inhabits northern China and southern Mongolia [2].

The camel economy is of considerable importance for arid countries. The dromedary camel can survive and produce a considerable amount of milk during recurrent and prolonged hot and dry periods [4]. Camel milk and meat are considered important sources of protein for a wide-ranging population [5]. Thus, camel milk is considered one of the most valuable food sources due to its nutritional value and medicinal properties, such as treatment of jaundice, tuberculosis, asthma, and anaemia, and as a laxative [6]. In addition, camel milk is rich with several inhibitory proteins, such as its high concentration of lysozyme, lactophorin (proteose peptone component-3), which is a member of the glycosylation-dependent cell adhesion molecule-1 (GlyCAM-1), and the peptidoglycan recognition protein (PGRP), which plays an important role in preventing adhesion and bacterial multiplication [7]. The female camel lactation period varies from 9 - 8 months and the estimated annual milk production ranges between 800 and 3600 litres [8]. The level of camel milk production is influenced by various factors, such as type of breed and the husbandry system [8]. The estimated camel meat production was increased from 123,000 tons in 1961 to 356,000 tons in 2009 [9]. The estimated contribution of camel meat to world meat production was $0.13 \%$ in general, and $0.45 \%$ to red meat production in 2009 [9]. The economic importance of camel meat is of significance as a nutritive value, beside its traditional remedial uses [10]. Camel meat is favored due to its low cholesterol content for those who suffer from problems of diabetes and high cholesterol or related medical conditions [10].

There is no evidence of resistance or susceptibility of certain camel breeds to certain infections. Nevertheless, in general camels are resistant to certain infec- 
tions, whereas they are highly susceptible to a wide range of infectious diseases. Camel susceptibility to infection with Brucella abortus and melitensis has been widely documented [11] [12]. Evidence of camel paratuberculosis infection was also voluminous [12] [13] and camel infestation with different parasites and protozoa was widely recorded [12] [14]. The susceptibility of camels to infections with different viral diseases has also been studied [12]. Various camel infectious diseases are considered prime zoonosis diseases that threaten public health, such as middle east respiratory syndrome coronavirus (MERS-CoV) [15] and tuberculosis [16].

Camel resistance is greatly influenced by adaptive immune responses, particularly cellular immunity. Vaccine development to combat camel diseases to enhance camel welfare depends greatly on detailed insights into the mechanisms of camel adaptive immune responses. Unfortunately, the available body of literature about the camel immune system and mechanisms of recognition and immunogenetic diversity suffers from wide gaps [17].

Although the available data on the camel immune system and its responses are scarce, in the last decade important information has been disclosed on some camel immune organs and the mucous associated lymphoid tissues (MALT) [18] [19]. On the molecular immunology level, data has become accessible about the diversity of antibody genes and the major histocompatibility (MHC) polymorphism that could define its repertoire [17].

Overall, this review has defined the areas of the camel immune systems that were extensively studied, hence the prospect of the research in the field of camel immune system could be anticipated. The major fields that urge for extensive exploration are the basic mechanisms of the antibody production by the B lymphocyte, mechanism of MHC restriction of T-cell activation and the major genetic and physiological elements that endorse camel immune responses under the harsh environment. The knowledge about the elements of the innate immunity like the toll like receptors, cytokines, and other inflammatory factors is slim and therefore research in the field of innate immunity is one of the prime priorities. In general, the unknown knowledge about the camel immune system is far greater than currently available data.

In this review, the primary focus is on camel immune organs and lymphoid tissues. The review will cover newly published data on the camel lymphocyte phenotypes and accessory cells, with an emphasis on their possible role in immune hemostasis in health and disease. Certain facets of immune responses to certain infectious diseases will be addressed. Finally, development in the field of immunodiagnostic as important tools in control and prevention measures was discussed.

\section{Organs and Tissues of the Dromedary Camel Immune System}

Functionally, the organs and tissues of the immune system of mammals can be 
classified as central (primary) organs and peripheral (secondary) organs.

\subsection{The Central Lymphatic Organs}

The primary lymphoid organs refer to organs in which lymphocytes are generated and undergo development and maturation.

\subsubsection{The Thymus Gland (Figure 1(A))}

In the dromedary camel, the thymus gland is located in the thoracic cavity, at the anterior superior mediastinum, in front of the heart and behind the sternum [20]. It may extend to the caudal forth part of the neck, where it can be seen between the trachea and the left external jugular vein [21]. Both lobes are surrounded by a thin connective tissue capsule from which thin connective tissue-septa are sent, dividing incompletely the lobe into lobules. These thymic lobules are irregular in outline and consist of an outer cortex and inner medulla (Figure 1(A)). The cortex is darkly stained, because of numerous T-lymphocytes (thymocytes). Beside the thymocytes, there are epithelial reticular (epithelioreticular) cells, which have stellate-shaped and are numerically much less than thymocytes [22]. In addition, numerous granulated cells of different shapes
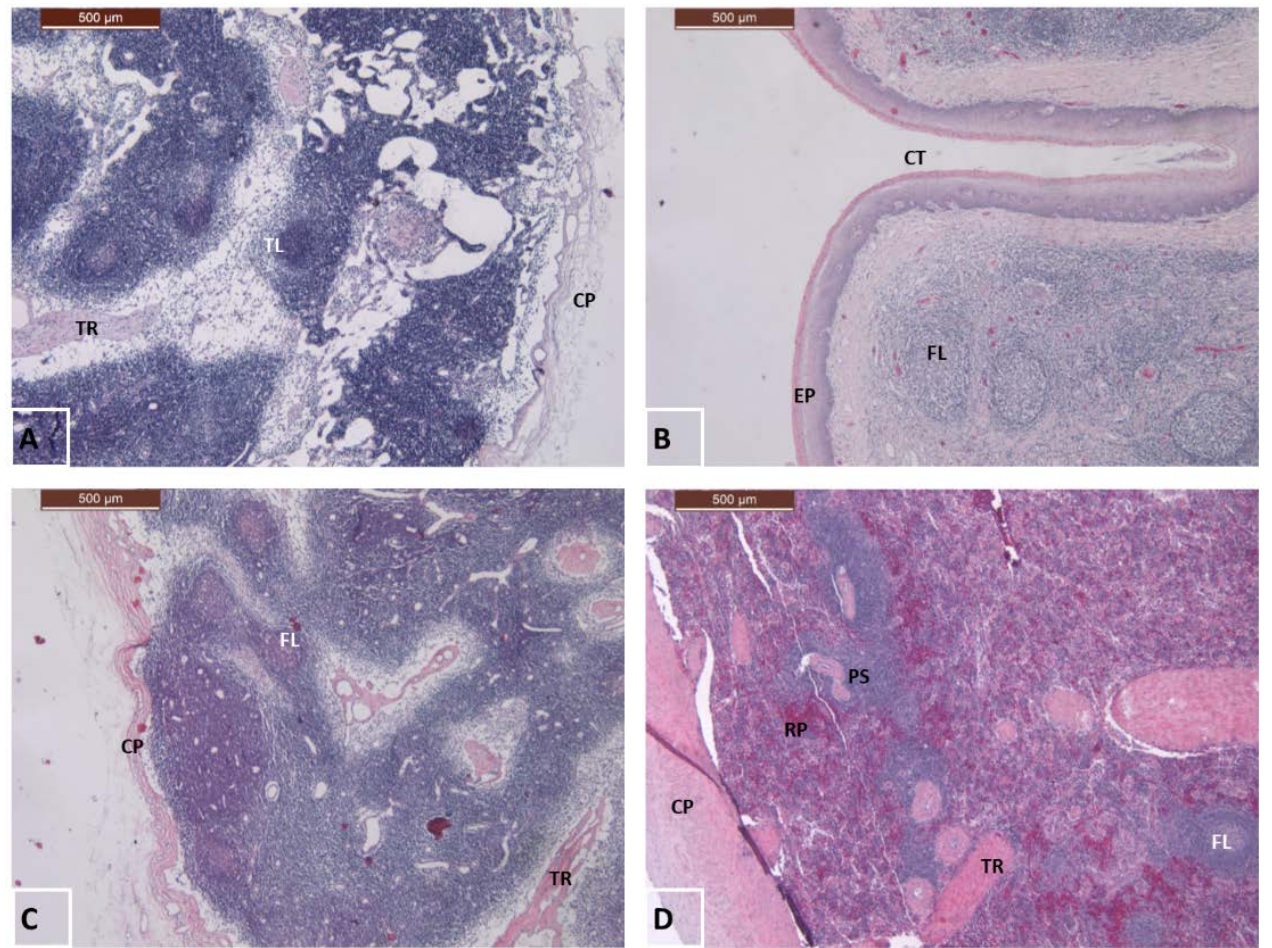

Figure 1. Some immune organs of camel; (A) Thymus gland showing the capsule (CP) and trabeculae (TR), the trabeculae divide the thymus into incomplete lobules with dark cortex and lighter medulla. (B) Palatine tonsil with deep crypt (CT) showing the stratified squamous epithelium (EP) and the lymphoid follicles (FL). (C) The lymph node of camel showing the capsule (CP) and the distribution of the lymphoid follicles (FL) within the parenchyma. (D) Spleen showing its thick capsule (CP) and trabeculae (TR), the whit pulp formed of lymphoid follicles (FL) and periarterial lymphatic sheath (PS) in between them the red pulp (RP) is located. (H and E stain, Scale bar: $500 \mu \mathrm{m})$. 
and sizes are observed in the interlobular connective tissue and occasionally adjacent to the cortex [23].

\subsubsection{Bone Marrow}

The literature lacks the histological details of the camel's bone marrow. The scant retrieved data indicated that camel's bone marrow is similar to that of other mammals [24].

\subsection{The Peripheral Lymphatic Organs}

\subsubsection{Mucosal Associated Lymphatic Tissue (MALT) \\ 1) Diffuse unencapsulated lymphatic tissue}

Camels have wide range of unencapsulated lymphoid tissues, mainly distributed in the lamina propria of the glandular stomach in the form of diffuse lymphatic tissue, solitary lymphoid nodules and aggregated lymphoid nodules [25]. On the other hand, there are few lymphoid tissues in the form of sporadic lymphocytes and plasma cells in the oesophagus and the non-glandular stomach. The Bronchial associated lymphoid tissue (BALT) of the camel is mainly displayed by isolated or aggregates of lymphoid follicles, which are scattered along the bronchial tree in the entire lung. The density of lymphoid tissue increases from the trachea to the lower graded branches (densest in the bronchioles) and then decreases at certain locations around respiratory bronchioles or among the pulmonary mesenchyme [26].

\section{2) Nodular lymphatic Tissue}

\section{a) Tonsils}

In a comprehensive study, Achaaban et al. (2016) described the anatomical and histological features of the three groups of tonsils of the dromedary camel (Figure 2). The group oropharyngeal comprises three components-the palatine,

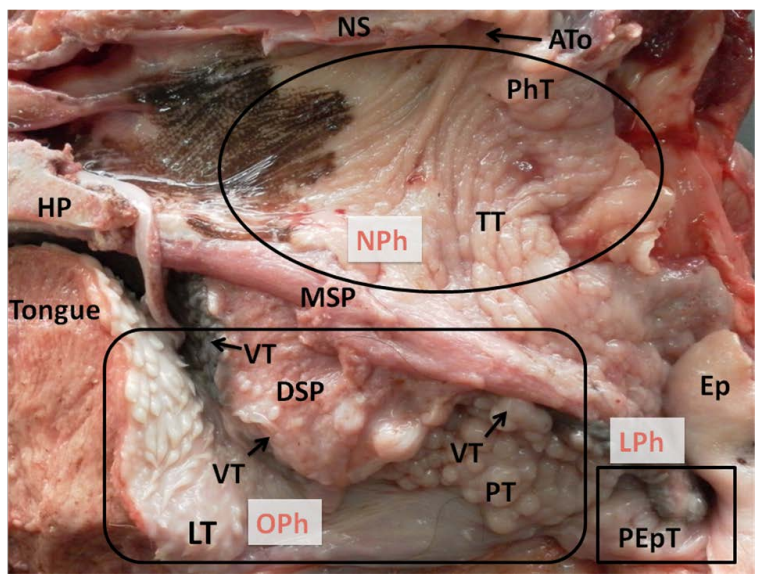

Figure 2. Sagittal section (right part) of camel head showing the tonsils localization within the oropharynx $(\mathrm{OPh})$, the nasopharynx $(\mathrm{NPh})$ and the laryngopharynx $(\mathrm{LPh}) ; \mathrm{LT}$ : lingual tonsil; VT: Velar tonsil; PT: Palatine tonsil; PEpT: Paraepiglotic tonsil; TT: Tubar tonsil; PhT: Pharyngeal tonsil; ATO: Auditory Tube opening; HP: Hard palate; MSP: Muscle of Soft Palate; DSP: Diverticulum of Soft Palate; Ep: Epiglotis; NS: Nasal septum (Courtesy of Dr Achaaban [27]) 
the lingual and the velar tonsils-whereas the group nasopharynx includes the pharyngeal and tubal tonsils, and the final group-the laryngopharynx-is formed of the paraepiglotic tonsil [27].

\section{i) The Palatine Tonsil}

This tonsil is well developed in dromedary camels, with several macroscopic nodules in the lateral wall of the oropharynx. It is located within a tonsillar fossulae, which extends between the palatoglossal and palatopharyngeal arches (Figure 2, Figure 3). Microscopically, the spherical masses of lymphatic cells are arranged into heavily cellular ovoid or spherical nodules and less populated internodular areas. The palatine tonsil is encapsulated within a thick layer of stratified squamous epithelium non-keratinized which is reflected inside the tonsil, forming a blind ended crypt (Figure 1(B)). But the high stratified squamous mucosal epithelium changes to thinner epithelium and is usually infiltrated with lymphocytes, forming a reticular epithelium [19] [27] [28].

\section{ii) The Lingual Tonsil}

This tonsil is formed of a cluster of spheroidal lymphoid masses at the root of the tongue protrusion into the oropharynx (Figure 2). The lingual tonsil of the dromedary camel is macroscopically visible at the root of the tongue in the form of several spherical macroscopic nodules protruding into the oropharynx [27] [28]. It has been reported that the crypt is not clearly visible in the lingual tonsil of the dromedary camel [27]. Zidan and Pabst (2019) described more than one crypt in the dromedary's lingual tonsils [29]. Histologically, the lingual tonsil of the camel is made of a cluster of lymphoid nodules and internodular tissues. The mucosal surface of each nodule is covered by a keratinized stratified squamous epithelium, with a similar epithelium of the lingual surface [27] [28].

\section{iii) The Velar (Soft Palate) Tonsil}

This tonsil is formed of disseminated nodules with crypts on the oropharyngeal (oral) surface of the soft palate, close to the junction with the hard palate (Figure 2; Figure 4) [27]. The nodules of the velar tonsil are formed of primary

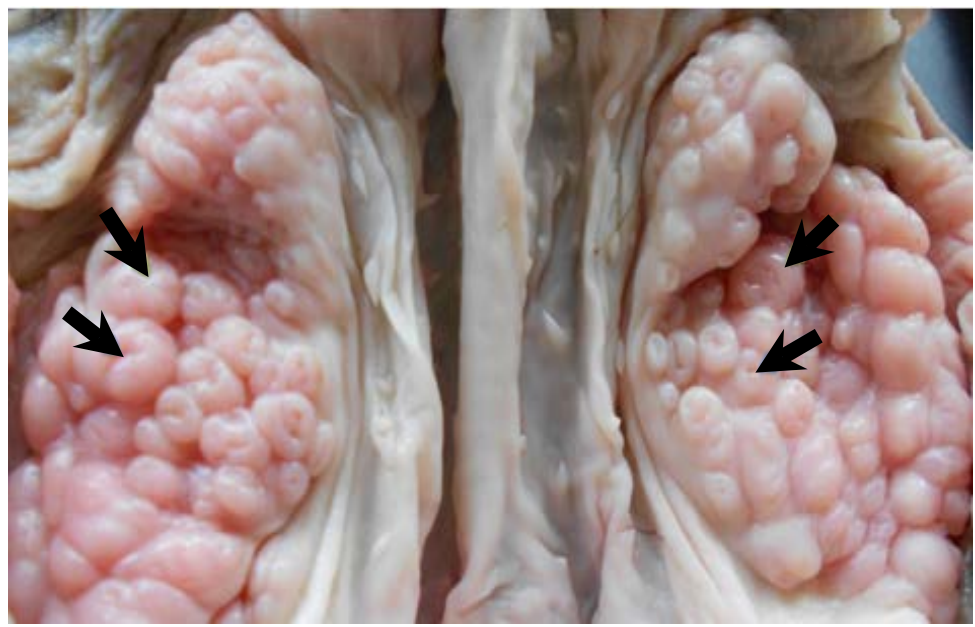

Figure 3. Dorsal view of the palatine tonsil of the camel showing the crypt opening (arrows). (Courtesy of Dr Achaaban [27]) 


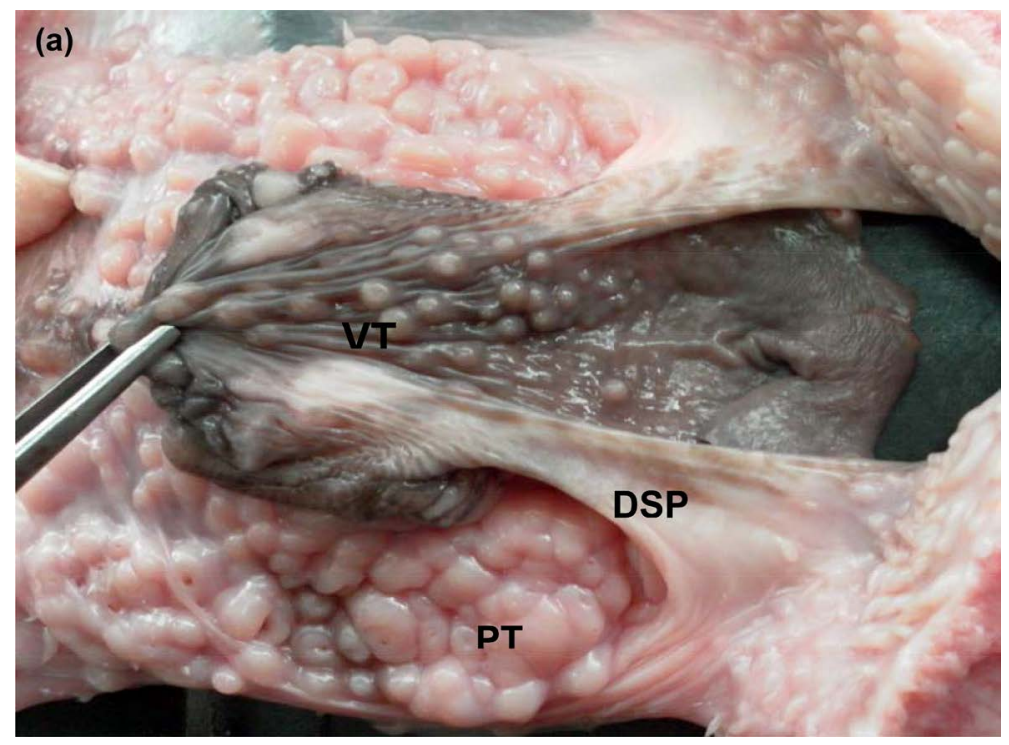

Figure 4. Dorsal view of the oro-pharynx of the camel showing the position of the velar tonsil (VT). PT: Palatine tonsil; DSP: Diverticulum of Soft Palate. (Courtesy of Dr Achaaban [27]).

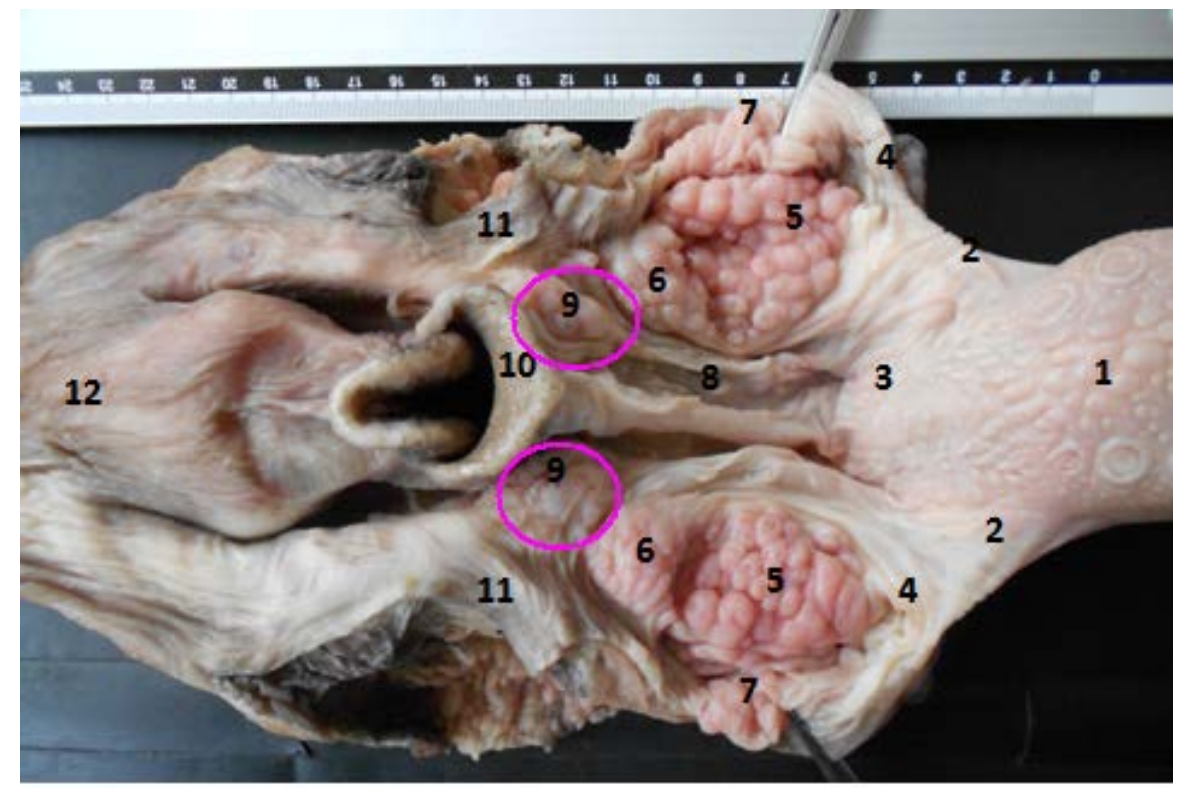

Figure 5. Dorsal view of the oropharynx and laryngopharynx of the camel showing the paraepiglotic tonsil location (Pink circles). 1: Tongue body; 2: Palatogloss arch; 3: Lingual Tonsil (Tongue root); 4: Soft palate diverticulum fold; 5 \& 6: Major and Minor lobes of palatine tonsil; 7: Velar tonsil; 8: Ventral wall of the oropharynx; 9: Paraepiglotic tonsil; 10: Epiglotis; 11: Palatopharyngeal arch; 12: Oesophagus vestibule. (Courtesy of Dr Achaaban [27]).

and secondary lymphoid follicles separated by parafollicular lymphoid tissue, distributed within the connective tissue of the soft palate. It is covered by stratified squamous keratinized epithelium [27] [30]. The nodule of this tonsil is provided with a crypt which is lined by a non-keratinized stratified squamous epithelium. Some lymphoid cells infiltrate the crypt epithelium overlying lymphoid 
follicles [27].

\section{iv) The Pharyngeal Tonsil}

In the dromedary camel, this tonsil is a prominent lymphoid structure located within the median part of the dorsal wall of the nasopharynx, behind the nasal septum (Figure 2). Histologically, this tonsil is represented by lymphoid nodules covered by stratified squamous keratinized [27].

\section{v) The Tubal Tonsil}

This tonsil is located on both lateral walls of the nasopharynx, close to the opening of the auditory tube (Figure 2). The lymphoid nodules of this tonsil are diffused and arranged within the epithelial folds of nasopharynx, resembling that of the pharyngeal tonsil [27].

\section{vi) The Paraepiglotic Tonsil}

This tonsil is located on both sides at the base of the epiglottis, forming circular clustered cryptic lymphoid nodules (Figure 2; Figure 5). Histologically, this tonsil has similar features to the oropharynx by forming smaller aggregates of lymphoid nodules molded together, constituting a very compact tonsil [27].

\section{b) Peyer's Patches (PPs)}

Peyer's patches, also known as intestinal tonsils, are subepithelial aggregations of lymphoid tissue located along the antimesenteric side of the small intestine. In young dromedary camels, the PPs are cup-shaped masses which elevate for about $1 \mathrm{~cm}$ above the luminal surface [31]. Each of these masses is formed of lymphoid nodules aggregately located in the submucosa, while some extend up to the lamina propria. These nodules are distributed around the lateral borders and the bottom of the patches. The number of nodules per patch in the ileum range between 25 27 in the cranial portion and $31-38$ in the caudal part. The diameter of the nodules ranges from $500-900 \mu \mathrm{m}$ [31]. In the adult dromedary camel, the number and size of the PPs are less than that of young camels. Similar to other species, the mucosa which is occupied by the PPs lacks any intestinal villi [32].

c) The Lymph Node (Figure 1(C))

The lymph node is encapsulated in lymphoid tissue and is designed to filter lymph. Zidan and Pabst (2012) demonstrated that the capsule of the lymph node is formed of two layers, an outer, thicker layer of connective tissue, and an inner thinner layer consisting mainly of smooth muscles [33]. From the capsule, the trabeculae extend toward the centre of the lymph node, dividing the parenchyma characteristically into incomplete lobules [33]. In this respect, two types of trabeculae have been recorded in the dromedary camel: type I is formed of two layers of connective tissue and muscle in which branches of blood and lymphatic vessels are located; type II is formed of smooth muscles only [34]. Moreover, the lymph node receives one or two large afferent lymphatics, which penetrate the capsule and may extend to the connective tissue seta, and are drained by four or five efferent lymphatics [34] [35].

d) The Spleen (Figure 1(D))

The spleen is the largest lymphatic organ in domestic animals [36]. In the 
dromedary camel, the spleen is crescent shaped and is located at the dorsocaudal aspect of the omentum [21]. The spleen is surrounded by thick connective tissue capsule and is covered externally by mesothelial cells [36]. The capsule can be easily subdivided into outer and inner layers: the outer layer is composed of connective tissue including collagen, elastic and fibroblast, in addition to a few smooth muscle cells, and the inner layer is formed of smooth muscles supported by connective tissues [36] [37]. The trabeculae, which are either vascular or avascular, extend from the capsule to the parenchyma [37]. The vascular trabeculae contain nerve fibers and arteries without veins, while the avascular can be further subdivided into primary and secondary trabeculae. The primary trabeculae are composed mainly of smooth muscle cells supported by reticular, collagen and elastic fibers [38]. The secondary trabeculae are formed of smooth muscle with reticular fibers [38].

The parenchyma of the spleen in the dromedary camel is made of white and red pulps. The white pulp is comprised of the periarterial lymphatic sheath (PALS) and lymphoid follicles [38]. The lymphoid follicles are spherical and sometimes indented on one side where the PALS is located [37] [38]. They are mainly occupied by B-lymphocytes; hence they represent the B-dependent zone in the spleen, whereas the PALS is considered the T-dependent zone [39].

\section{The Camel Antibody Isotypes and Their Tissue Distribution}

Antibody is one of the most important multifunctional effector elements of humoral immune responses. Antibody is the secreted receptor of the B-lymphocyte [40]. The molecule is constructed of a pair of light (L) chains (25 KD) and a pair of heavy $(\mathrm{H})$ chains $(50 \mathrm{KD})$ [40]. Two types of L chain-the kappa $(\kappa)$ and lambda $(\lambda)$ light chains-exist due to the subtle differences in the amino acid sequences. Both light chains are found in the antibody of almost all camel species. Each antibody light chain either is of $\kappa$ or $\lambda$ type, but not both [40]. The amino acids of the $\mathrm{L}$ and $\mathrm{H}$ chains are arranged in multiple globular structures known as domains. Each domain is made up of 110 amino acids. The constant domains of $\mathrm{L}$ and $\mathrm{H}$ chains are tightly folded, whereas the folds of the variable (V) domains of both chains are flexible. The flexible loops of the variable domains send finger like projections to construct the antigen binding site.

The specificity of the antibody is based on antibody repertoire, which defines the extent to which the antibody can respond to a wide range of antigens. The antibody repertoire is generated by DNA rearrangements, or what is known as somatic recombination, during B-cells development [40]. The repertoire is expanded further by the process of somatic hypermutation in the developed B-cells.

The genes that encode immunoglobulin are arranged in three loci-the $\kappa$ and $\lambda$ genes of the $\mathrm{L}$ chain, and the $\mathrm{H}$ chain. The isotypes of the immunoglobulin are defined by the constant $(\mathrm{C})$ region of the $\mathrm{H}$ chains. The $\mathrm{C}$ region of the $\mathrm{H}$ chains 
gene contains series of $\mathrm{C}$ segments that are arranged consequently in which each region corresponds to each of the antibody isotypes. The activated B cells are expressed one at a time, starting with IgM.

The diversity of the antibody specificity is generated in four main ways: two are a result of recombination process during $B$ cell development; the third is due to the vast probability of $\mathrm{L}$ and $\mathrm{H}$ chains combinations (the probability of the $\mathrm{H}$ and $\mathrm{L}$ chains pairing is one of the major mechanisms that expand the antibody repertoire); and the fourth way is generated by mutation of the $\mathrm{V}$ loci of the rearranged DNA in the mature B cells [40]. The diversity of the repertoire can be expanded further by imprecise joining of $\mathrm{V}, \mathrm{D}$, and $\mathrm{J}$ gene segments and somatic hypermutation.

The diversity of the complementary determining region-3 (CDR3) of the $\mathrm{H}$ and $\mathrm{L}$ chains is dramatically increased by addition and deletion of nucleotides in the junction between gene segments [40].

\subsection{The Camel Antibody Isotypes and their Genes}

Similar to most vertebrates, the camel antibody is made up of $\operatorname{IgG}$, IgM, IgA and IgE classes. Camel IgG comprises of three subclasses, namely, IgG1, IgG2 and IgG3. IgG1 has the conventional structure-a pair of $\mathrm{L}$ and $\mathrm{H}$ chains, while IgG2 and IgG3 are only made of $\mathrm{H}$ chain and lack $\mathrm{L}$ chain and the (CH1) domain. The IgG2 and IgG3 subclasses account for about $75 \%$ of the total antibody classes [41] (see Table 1). The camel germline repertoire contains nine $\gamma$ genes. Five of these $\gamma$ genes are only functional as they were detected in the rearranged Ig genes [42]. Two of these five genes encode the $\mathrm{H}$ chain of the conventional antibodies IgG1a and IgG1b, while the other three genes are allocated for the production of $\operatorname{IgG} 2$ and $\operatorname{IgG} 3(\gamma 2 \mathrm{a}, \gamma 2 \mathrm{c}, \gamma 3)$ [42]. The genes that encode the $\mathrm{H}$ chain of the conventional antibody and the $\mathrm{H}$ chain of the camel heavy chain-only antibodies (HCAbs) are located in two different germline genes [41]. The camel L chain is also made of $\kappa$ and $\lambda$ variants [43]. The two variants of the IgG1 are constructed of different numbers of amino acids in the hinge region. The IgG1a variant has 19 amino acids whereas IgG1b has 12 residues in that region [43] (see Table 1).

A phylogenic analysis of the camel heavy chain reveals that the camel heavy chain framework VH3 is closely similar to that of the human while the VH4 framework similarity is of a lesser extent [42] [43]. It has been suggested that

Table 1. The camel IgG subclasses and their genes.

\begin{tabular}{cccc}
\hline IgG subclass & Type of the subclass & Variants & $\begin{array}{c}\text { Amino Acids } \\
\text { at hinge region }\end{array}$ \\
\hline \multirow{2}{*}{ IgG1 } & H and L $(\kappa$ and $\lambda$ ) chains (conventional) & IgGla, IgG1b & $\begin{array}{c}\text { IgG1a: } 19 \\
\text { IgG1b: } 12\end{array}$ \\
\multirow{2}{*}{ IgG2 } & Heavy chain Ab (HCAbs) & $\gamma 2 \mathrm{a}, \gamma 2 \mathrm{c}$ & $\gamma 2 \mathrm{a}: 35$ \\
IgG3 & Heavy chain Ab (HCAbs) & $\gamma 3$ & $\gamma 3: 12$ \\
\hline
\end{tabular}


two B cells lineages could be exist, with one expressing the classic four chains antibody (IgG1), while the other lineage expresses the HCAbs [41].

\subsection{The HCAbs}

The HCAbs, IgG2 and IgG3 differ from each other by their adsorption behavior to A protein and the molecular weight of the $\mathrm{H}$ chain [42]. The IgG2 and IgG3 sub isotype $(\gamma 2 \mathrm{a}, \gamma 2 \mathrm{c}, \gamma 3)$ encode different hinge regions. They are made of 35 amino acids, 12 amino acids and 15 amino acids respectively [41] [42] (see Table 1). The hinge region of the HCAbs is in direct contact with the variable heavy domains [41]. The $\mathrm{V}$ domains of the heavy chains $\left(\mathrm{V}_{\mathrm{H}} \mathrm{H}\right)$ of the HCAbs are distinct due to the presence of few highly conserved amino acids [42].

The intrinsic sequence of $\mathrm{V}_{\mathrm{H}} \mathrm{H}$ is more diverse than that of the variable heavy of the conventional antibody. The mutation hotspots of the $\mathrm{V}_{\mathrm{H}} \mathrm{H}$ are concentrated around the CDR1. The mutation mainly arises during the affinity maturation [41] [42].

The antigen-binding site of the HCAbs is constructed of three, instead of six, loops in the conventional antibodies. The complementary determining region 3 (CDR3) of the HCAbs is quite distinct in that it has a longer loop to compensate for the short antigen binding site in these antibodies [42]. The long CDR3 enhances its accessibility and increase its paratope diversity [42]. Similar to camels, bovine antibodies also have large CDR3. However, bovine CDR3 is known for its ultralong subset, which ranges from 50 to 60 amino acids [44].

\subsection{The Tissue Distribution of the Camel IgA+ and IgG+ Cells}

Studies on the tissue distribution of different camel antibody classes and subclasses are scant. A few studies on the antibody isotypes and antibody secretory cells distribution were recorded [45] [46]. The B-lymphocytes that express $\operatorname{Ig} \mathrm{A}^{+}$ and $\mathrm{IgG}^{+}$cells are diffusely distributed in the non-subepithelial area of the lamina propria (LP) of the aggregated lymphoid nodules area (ALNA), and few are in the subepithelial dome (SED) of the camel intestine [45] [46]. The IgA ${ }^{+}$cells are detected in the SED of younger and middle-aged camels more than the old camels. The concentrations of the $\mathrm{IgA}^{+}$and $\mathrm{IgG}^{+}$populations in the non-SED are greatly affected by aging [45] [46]. It has been clearly indicated that aging has a significant impact on the density and distribution of $\operatorname{IgA}^{+}$and $\operatorname{IgG}^{+}$cells [45]. Existing studies on the IgG antibody secretory cells (ASCs) distribution in the small intestine have shown that they are densely scattered in the LP, and some are aggregated around the intestinal glands [45]. The IgG ASCs are evenly distributed in the duodenum, jejunum and ileum. However, the density of the ASCs is highest from the middle segment of the duodenum to the middle segment of the jejunum, and decreases in the ileum [45] [46]. The scattered distribution of the IgG and IgA ASCs in the small intestine is of significant importance for providing full-protection and immune surveillance of the mucosal immune homeostasis and intestinal integrity [45] [46]. The densities of IgA ASCs are great- 
er than IgG ASCs in the duodenum, jejunum and ileum of young and pubertal camels [46].

\subsection{The Antibody Concentration in the Colostrum}

The colostrum is a vital resource of maternal immunity and is essential for the passive immunization of newborn camels. The concentration of IgG in the camel colostrum has not been explored in detail. Although the IgG isotype is abundant in the colostrum, the relative levels of IgG1, IgG2 and IgG3 have not been clarified [41]. The epitheliochorial nature of the camel placenta urges the transfer of maternal immunity through the colostrum suckling. The study of the camel colostrum constituents of the antibody isotypes confirmed the presence of IgM, IgG and IgA in the colostrum [41].

\subsection{The Therapeutic Applications of HCAbs}

HCAbs clinical applications have been widely reported in different medical studies; however, none of the HCAbs-derived products developed by several manufacturers have reached the market or passed to phase IV. Without affecting their safety or efficacy, HCAbs in some clinical trials have shown a lower incidence of antidrug antibodies (3\%) [47], whereas others, although small in number, have resulted in high immune adverse effects that necessitated terminating the trials prematurely [48].

As diagnostic tools, HCAbs are employed in immunodiagnostic assays of infectious diseases [49], such as Trypanosoma congolense in plasma [50] and Listeria monocytogenes in milk [51], and for protein detection such as enzymes produced by aerobic and anaerobic bacteria [52]. Low molecular weight molecules, such as methotrexate, have also been detected by HCAbs [53]. For in vivo and in vitro imaging diagnosis, HCAbs are one of the strong applications for their simple functionalization with radiolabels or fluorescent probes [54]. The epidermal growth factor receptor (EGFR), which is related to different epithelial cell tumours, is a biomarker used to localize tumours, or could be coupled to medications to treat some types of cancer or used in imaging studies [55].

As therapeutic tools, HCAbs have been used to remove immunoglobulins in patients with high titres of circulating autoantibodies, as in the case of systemic lupus erythematosus [56]. In infectious diseases, HCAbs have been developed as neutralizing antibodies against $\mathrm{H} 5 \mathrm{~N} 1$ influenza virus to prevent the virus attachment to the host cells. [57] HCAbs were seen effective as anti-Clostridium difficile toxin by preventing the induction of cytotoxicity [58]. Treatment of human respiratory syncytial virus infection through pulmonary delivery was also recorded [59]. HCAbs have been attempted to treat neurodegenerative diseases, such as Alzheimer's [60] and Parkinson's diseases [61]. For toxicity management, a higher neutralizing capacity was found when HCAbs were used against snake venom and scorpion toxins [62]. HCAbs in vivo studies appeared to be efficiently delivered across blood-brain barrier and might be used to carry any 
cargos into the brain [63]. HCAbs conjugates showed potential efficacy for cancer immunotherapy. Conjugates to EGFR could be used to treat solid tumours [64].

Compared to a renal clearance limit of $60 \mathrm{kDa}$, HCAbs smaller size of $15 \mathrm{kDa}$ allow them to rapidly clear from the blood when used as parenteral treatment. To overcome this problem, HCAbs should be ligated to large proteins such as albumin or immunoglobulin by using bivalent formats [65]. Some products derived from HCAbs have succeeded in passing phase I and II trials, although they are still in the pipeline [62]. The accomplishment of HCAbs treatment will be achieved if more patient-friendly administration (topical, oral, or inhalation) products are developed. Nevertheless, the short period of time was found to produce HCAbs owing to their low-cost compared to conventional antibodies; therefore, HCAbs are precious in human medicine, and have much to offer as a research tool in the scientific community.

\section{Immune Camel Cell Markers and Their Tissue Distribution}

Cluster of differentiation (CD) are cell surface molecules that are considered important cell surface markers for defining cells' immunophenotyping, and are a vital tool in diagnosis and cell classification [66]. Most CD markers play an important role in conveying signal transduction and cell-cell interaction [66]. The cellular markers' expression could be important in different disease as indicators of disease regression or progression 18] [67].

One of the most important CD markers is the adhesion molecules (AM) that are involved in facilitating the cells to bind with other cells or with extracellular matrix. The interaction between cell AMs can be considered identical to the binding of a ligand to its receptor. The most important AMs are the immunoglobulin superfamily—integrins, cadherins, and selectins [68] [69] [70]. AMs are vital for the cellular homeostasis of different tissues by mediating cellular trafficking and regulating the movement of leukocytes through cell-cell interaction [71].

Another important cells marker is the chemokine receptor, which acts as a ligand for the chemokines, the small secreted proteins that are mainly involved in the regulation of cell migration [72]. The chemokines facilitate their effects through the cell surface $G$ protein-coupled with heptahelical chemokine receptors [72]. The chemokines are classified according to the cysteine moieties of the chemokine, according to which the families are CC, CXC, CX3C and XC chemokines [72].

\subsection{Markers of Camel Lymphocytes and Other Leukocytes and Their Tissue Distribution (zt2)}

Comprehensive study of camel cell markers is hindered by absence of specific anti-camel CD markers antibodies. However, in the last decade major efforts have led to the identification of several important markers, especially that of the 
Table 2. The CD markers and adhesion molecules (Ad) expressed by the camel immune cells and lymphoid tissues.

\begin{tabular}{|c|c|c|c|c|}
\hline$C D$ markers and $A d$ & Cells or Tissue(s) & Location & Health & Infected \\
\hline $\mathrm{CD} 4^{+}$ & T-helper lymphocyte & Blood & $\checkmark$ & \\
\hline $\mathrm{CD} 25^{+}$ & lymphocyte & Intestine & & $\sqrt{ }$ \\
\hline$\gamma \delta$ TCR & Lymphocyte & Blood & $\checkmark$ & $\checkmark$ \\
\hline $\mathrm{WC1}^{+}$ & Lymphocyte & $\begin{array}{l}\text { Blood, supramammary } \\
\text { lymph node, intestine }\end{array}$ & $\checkmark$ & $\checkmark$ \\
\hline $\mathrm{CD}^{+}$ & T-cytotoxic lymphocyte & $\begin{array}{l}\text { Blood, mammary gland, } \\
\text { intestine }\end{array}$ & $\checkmark$ & $\checkmark$ \\
\hline CD11a, b, CD18 & Lymphocyte, leukocytes & Blood, mammary tissue & $\checkmark$ & \\
\hline CD11c & leukocytes & intestine & & $\checkmark$ \\
\hline CD62L & Lymphocyte, leukocytes & Blood, mammary gland & $\checkmark$ & $\checkmark$ \\
\hline MAdCAM-1 & Mesenteric lymph node & Mammary, intestine & $\checkmark$ & $\sqrt{ }$ \\
\hline $\mathrm{CD} 14^{+}$ & Monocytes, macrophage & Blood, intestine & $\checkmark$ & $\checkmark$ \\
\hline CD163, MHC-II & Monocyte, macrophage & Blood & $\checkmark$ & \\
\hline CXCR2 & Mammary tissues, & mammary gland & & $\checkmark$ \\
\hline LPAM-1 & leukocytes & mammary gland & $\checkmark$ & $\checkmark$ \\
\hline CX3CR1 & Macrophage & Intestine & & $\checkmark$ \\
\hline
\end{tabular}

camel lymphocytes, using anti-human, mice, rat and bovine markers antibodies [73] [74] [75]. The CD markers of the camel lymphocytes in the blood of adult and new-born camels have been studied with flowcytometry [73] [76] [77]. Analysis of the CD markers on the camel lymphocytes in the peripheral blood of newborn camels indicated a higher expression of $\gamma \delta$ cells and B cells than in adult camels, whereas the expression of the $\mathrm{CD} 4^{+} \mathrm{T}$-helper cells in camel calves was less than in adult camels [77]. Expressions of the AM, CD11a, CD11b and CD18 on camel calves' leukocytes and lymphocytes were significantly lower than in adult camel cells [77]. A low AM molecule expression in newborn leukocytes could be due to a reduction in the migratory activity of the leukocyte populations [77]. Analysis of different camel lymphocyte phenotypes indicated that $83 \%$ are naïve $\mathrm{CD} 4^{+} \mathrm{CD} 11 \mathrm{a}$ and $\mathrm{CD} 44$, whereas $13 \%$ of the lymphocytes are effector cells with $\mathrm{CD} 4^{+}, \mathrm{CD} 11 \mathrm{a}$ and $\mathrm{CD} 44^{\mathrm{hi}}[76]$. On the other hand, bovine lymphocytes consist of $23 \% \mathrm{~B}$ cells, $20 \% \mathrm{CD}^{+}$and $6 \% \mathrm{WC1}^{+}$. The $\mathrm{WC1}^{+}$camel lymphocytes differ from bovine lymphocytes in their higher expression of AMs $\mathrm{CD} 11 \mathrm{~b}$ and $\mathrm{CD} 62 \mathrm{~L}$ [76]. The expression rate of the $\mathrm{WC1}^{+}$on the lymphocytes of young camels is higher than in adults, whereas the $\mathrm{CD} 4^{+}$expression is higher on the effector adult camel lymphocytes [76].

The expression of the lymphocyte markers in camel mammary glands and related lymph nodes were revealed in studies employing the immunohistochemical technique and using immunoperoxidase [74]. The $\mathrm{CD} 8^{+} \mathrm{T}$ cells were detected in lactating and non-lactating mammary alveolar tissues and the supramammary 
lymph nodes, with the highest expression observed in lactating glands. $\mathrm{WC1}^{+}$ expression was evident in mammary tissues and supramammary lymph nodes at both the lactating and non-lactating stage; however, the expression was higher in the non-lactating period [74]. Expressions of $\mathrm{CD}^{+}$and $\mathrm{CD} 20^{+}$were not detected at all. In addition, the over expression of $\mathrm{WC1}^{+}$in the non-lactating mammary tissues reflects the importance of these cells at this stage, in which major immunological changes occur [78]. The over expressions of the mucosal addressin cell-adhesion molecule-1 (MAdCAM-1) and the $\mathrm{WC1}^{+}$molecules at the late lactation period indicates that these molecules are essential for up-regulating of the immune responses at this period, during which mammary glands are highly susceptible to mastitis.

The phenotypes of camel monocyte, expressing $\mathrm{CD} 172 \mathrm{a}^{+}$, were revealed using anti-CD14 ${ }^{+}, \mathrm{CD} 163$ and MHC-II antibodies [79] (see Table 3). According to the rate of the expression of these $\mathrm{CD}$ markers, it was shown that the expression of the monocyte phenotypes were as follows, the monocytes-I (Mo-I) phenotype has a high expression of $\mathrm{CD} 14^{+}$and $\mathrm{CD} 163$ and a low MHC-II expression, while the Monocyte-II (Mo-II) phenotype was characterized by a high expression of all three molecules. In contrast to the Mo-I phenotype, the Monocyte-III (Mo-III) phenotype has a low expression of $\mathrm{CD} 14^{+}$and $\mathrm{CD} 163$ and a high expression of MHC-II [79]. The Mo-II was seen as the prime phenotype for inflammatory responses, and it is present in high levels in adult camels, whereas newborn animals have a lower percentage of the Mo-II phenotype. New-born monocytes indicated high expression of CD172a ${ }^{+}$and CD163 but fewer CD14 $4^{+}$and MHC-II molecules [79]. In addition to the variation in the expression of the previous $\mathrm{CD}$ markers in adult camels, it was also noticed that these phenotypes indicated a variation in the expression of the AM. The Mo-II and Mo-III phenotypes have shown a high expression of CD11a, while Mo-I has indicated a high CD18 ${ }^{+}$expression. However, the CD11b showed high expression of Mo-I and Mo-II, especially the monocytes that have a high expression of CD14 $4^{+}$and MHC-II [79] (see Table 3). The camel monocyte phenotypes Mo-I, Mo-II and Mo-III could be considered as the counterpart to the bovine classical, intermediate and non-classical monocyte phenotypes respectively. [79].

Camels with endometritis have indicated the elevation of the monocyte Mo-II

Table 3. The phenotypes of adult camel monocyte.

\begin{tabular}{cccc}
\hline \multicolumn{3}{c}{ Phenotypes } \\
\hline Markers & Mo-I & Mo-II & Mo-III \\
\hline CD11a & & High & High \\
CD18 & High & Low & Low \\
CD11b, CD14, MHC-II & High & High & \\
CD14, CD163 & High & High & Low \\
NHC-II & Low & High & High \\
\hline
\end{tabular}


phenotype with a distinct reduction in the Mo-III phenotype. Furthermore, the AM expression revealed an obvious decrease in the inflammatory monocytes [80].

Study of the camel cells markers of mammary glands with mastitis revealed a significant expression of the chemokine receptor CXCR2 and the adhesion molecules CD11a/CD18 and CD62L [81]. CD62L is an important selectin that mediates the naive lymphocytes to the peripheral lymph nodes and other mucosal associated lymphoid tissue [82]. An important finding in the study of camel milk from infected mammary glands detected Peyer's patches adhesion molecule-1 (LPAM-1) [81]. MAdCAM-1 promotes the homing of leukocytes expressing LPAM-1 to mucosal tissue [83]. This selective expression of MAdCAM-1 in different tissues is known to be a prime factor that mediates the specific migration of lymphocytes. For instance, the expressed MAdCAM-1 in the mesenteric lymph node or Peyer's patches (PP) has a selective binding with L-selectin to the specific glycosylation modification. However, the MAdCAM-1 expression on the high endothelial venules around the mammary glands lobules mediates the selective binding to LPAM-1 but not L-selectin [69]. However, it has been demonstrated that bovine mammary tissues lack distinct expression of MAdCAM-1 due to very low MAdCAM-1 mRNA transcriptional activity [68].

The nature of the $\mathrm{CD}$ markers expressed in the intestine of camels naturally infected with Mycobacterium avium subspecies paratuberculosis (MAP) has also been explored [18]. The expression of the markers $\mathrm{CD}^{+}, \mathrm{CD}^{2} 5^{+}, \mathrm{CD} 11 \mathrm{c}^{+}$, $\mathrm{CD}_{14}{ }^{+}, \mathrm{WC}^{+}, \mathrm{CX} 3 \mathrm{CR} 1$, and MAdCAM-1 were significantly elevated in the ileum and mesenteric lymph node of older camels in comparison to young camels [18]. The overall results indicated extensive presence of different lymphocyte subsets, dendritic cells and macrophages that play vital role in orchestrating the intestinal homeostasis and the immune responses to MAP infection [18].

\subsection{Peculiar Expression of Certain Cellular Markers and Their Possible Function}

\subsubsection{The LPAM-I and MAdCAM-1 Expression}

LPAM-1 integrin is constructed from subunits $\alpha 4$ and $\beta 7$ and expressed on the lymphocytes, monocytes, eosinophils and basophils, but not on neutrophils. LPAM-1 is the specific ligand of MAdCAM-1. The leukocytes homing to mucosal tissue are facilitated by the expression of the MAdCAM-1 [83]. Lymphocyte trafficking to the mammary glands is under the influence of adhesion molecules and their expression is vital for determining the cellular populations of the mammary glands in health and disease [70].

The lymphocytes' recirculation is divided into either peripheral or mucosal in nature. Hence a difference has been shown in the lymphocyte recirculation from mucosal and peripheral tissue between the mammary glands of the ruminant and other monogastric animals. It appears that the ruminant cell trafficking pathway is not part of the common mucosal immune system as it was defined for monogastric mammals. The mucosa of monogastric mammalian organs ex- 
press MAdCAM-1, as in mice at PP, gut lamina properia, and the mesenteric lymph node; however, in ruminants, MAdCAM-1 expression is missing in these tissues [68] [70]. According to this finding, it was therefore clearly demonstrated that lymphocytes that home to MAdCAM-1 expressing tissues are of mucosal origin, as in monogastric animals. Cells that home to tissues that lack MAdCAM-1 expression are of a peripheral nature, as in most ruminant animals. The origin of the cells' trafficking plays a major role in dictating the route of vaccination and the pathogenesis of different mammary gland infections [84].

Immunostaining and flowcytometry studies have proven beyond doubt the expression of MAdCAM-1 and LPMA-1 in healthy camels, emphasizing that the camel is closer to monogastric animals in this respect [74] [81]. Hence, the possible mucosal nature of cell trafficking to camel mammary glands will merit important consideration in the treatment of mastitis and approaches to vaccinations for camel mastitis. In addition, the possible mucosal nature of camel mammary glands could provide a convenient model to exploit the immune responses that are essential for designing effective therapeutic approaches for humans that share the mucosal nature of cell trafficking with camels [74].

\subsubsection{The CX3CR1 Expression}

Analysis of the CD markers of the camel intestine and the related lymph nodes naturally infected with MAP revealed a peculiar expression of the chemokine receptor CX3CR1, which is expressed by special lineage of intestinal macrophages [85]. The CX3CR1 macrophages play a central role in the regulation of intestinal immune homeostasis, mucosal defence and maintaining the barrier structure. The peculiar activity of the CX3CR1 macrophages in the human intestine lies in reducing the lumen microbial load and acting as an antigen sampler by bidirectionally shuttling through the intestinal barriers. The cells are also important for excluding the pathogens that are traversed to the intestinal epithelium [85]. The CX3CR1 macrophages are crucial for regulating intestinal tolerance due to their extreme susceptibility to any changes in the gut environment [85]. In cattle, however, studies on CX3CR1 macrophage phenotype are scarce. The expression of the CX3CR1 in the camel intestine could be considered extraordinary and in need of further investigation.

Therefore, the high expression of the CX3CR1 macrophages and the expression of the LPMA-1 and MAdCAM-1 in different healthy and diseased camel tissues is novel and unprecedented. The CX3CR1 and MAdCAM-1 expression could play a certain role in the camel immunopathological responses to MAP infection in the intestines, a subject meriting extensive exploration [18].

\section{Immune Responses to Infections and Infestations}

\subsection{Antibody Immune Responses}

As vertebrate, camels produce the conventional immunoglobulin classes, IgM IgD, IgG, IgA, and IgE [41]. IgA plays a key role in the camel's mucosal immunity by modulating immune exclusion, inhibiting inflammation and allergic re- 
actions [86]. For instance, IgA was predominantly detected at the local mucosal sites of helminth infestation [87]. On the other hand, IgG is predominant in the serum of infected camels. IgE, however, is produced in low concentrations in mucosa and in serum. IgE is involved in immediate hypersensitivity reactions and parasitic infestation in camels [87] [88]. The predominance of IgG in the colostrum is crucial for the transfer of maternal immunity to newborn camels during the first 24 hours post parturition [89]. Maternal antibody transfer to camel calves is seen as critical for protecting against rotavirus infections in the endemic areas [90].

\subsection{Cellular Immune Responses}

Major histocompatibility complex (MHC) genes play a pivotal role in the regulation of cellular immune responses, most critically during host-pathogen interactions [91]. The MHC locus is located on chromosome 20 in Camelus dromedarius [92]. Sequencing studies on the camels' MHC genes of the three breeds of old-world camels have indicated that they are of low genetic diversity [92] [93]. However, the question is whether the low diversity of the camel genomes could be explained by the low MHC diversity [92]. Recent study has shown significant low genetic diversity of both MHC class I and class II genes [93]. Nevertheless, the question remains as to whether the low MHC diversity might be linked to the low diversity of the camel genomes [92].

The major leukocytes that play a central role in camel cellular immunity include lymphocytes, monocytes, neutrophils, dendritic cells, eosinophils and basophils.

Lymphocytes are the most abundant leukocyte subpopulation in camel blood, followed by neutrophils [17]. $\mathrm{T}$ and $\mathrm{B}$ lymphocytes, together with the antigen processing cells (APC), are critical for the regulation of the adaptive immune response [92]. Subsets of the B-lymphocytes B-1 or B-2 have been reported in camel blood [94]. However, there is scant information about the camel T-lymphocyte subsets. Regarding the T cell receptor (TCR), two types of TCR- $\alpha \beta$ and $\gamma \delta$ have been reported [88] [92].

$\gamma \delta$ T-lymphocytes are likely to predominate both epithelial and mucosal sites [87] [92]. $\gamma \delta$ T-lymphocytes have the characteristics of an innate-like immune response as well as adaptive responses. $\gamma \delta$ T-lymphocytes play a major role during the innate immunity and the early phase of the cell-mediated response. They also act as professional antigen processing cells (APCs) by processing different types of antigens, such as responding to unconventional antigens like lipid in an MHC-independent manner [76]. They show cytotoxic activity by eliminating the infected macrophages and are considered a major source of IFN- $\gamma$. [92] [95]. Camels' $\alpha \beta$ T-lymphocyte, however, recognizes peptide antigens presented on MHC molecules. The majority of T-cells in camel blood are $\alpha \beta \mathrm{T}$ cells. Monitoring the T-cells in camel blood at different ages has revealed that effector $\mathrm{CD} 4^{+}$ T-cell percentages were elevated in old camels compared to young camels [76]. 
Proinflammatory cytokines are pivotal players in priming and regulating cell-mediated immunity (CMI). For instance, Th1 cytokines, such as interferon- $\gamma($ IFN- $\gamma$ ) and interleukin-2 (IL-2), are involved in protection against intracellular pathogens through propagation of $\mathrm{CD}^{+}$lymphocytes as cytotoxic T-cells and macrophage activation, in particular during gastrointestinal parasite infestation [87]. $\mathrm{CD}^{+}$lymphocytes mediate the killing of the intracellular pathogens or damaged cells through MHC-restriction approach [87]. Regulatory T-cells (Treg) activity was reported in camels [96], as well as T-helper 17 (Th17) activity, mainly due to the stimulation of the toll-like receptor (TLR)-ligands [87].

Camel monocytes are innate immune cells playing an essential role in maintaining innate immunity [80] by opsonisation, either by Ig and/or complement [88] [97]. Monocytes are important for initiating the adaptive immune response by processing microbial antigens and activating T-cells [88].

Dendritic cells (DCs), on the other hand, are innate immunity cells which are well known as APC [98]. DCs can be detected in most of the body tissues, particularly the skin, mucosa and in the secondary lymphoid tissues [88] [99]. DCs express TLR for recognition of the pathogen associated molecular patterns (PAMPs) of invading parasites, and can prime specific immunity by antigen recognition associated with MHC-II restriction [100] [101]. DCs play a central role in antiviral responses and are able to regulate certain autoimmune diseases [88].

Neutrophils are important APCs which kill and present invading microorganisms. They secret copious pro-inflammatory cytokines in response to pathogens such as interleukin-1 (IL-1), interleukin-6 (IL-6), interleukin-12 (IL-12) and tumour necrosis factor- $\alpha$ (TNF- $\alpha$ ) [95]. Neutrophils play a key role in the initiation and direction of adaptive T-cell immunity by bacterial opsonization [102]. Camel neutrophils exhibit an oxidative respiratory burst against Staphylococcus aureus similar to the neutrophils of other species [103]. CD14 markers expressed on neutrophils mediate the TNF- $\alpha$ secretion in response to lipopolysaccharide (LPS) in the mammary glands [104].

There is evidence that camel eosinophils might express MHC antigen after stimulation by granulocyte-macrophage colony stimulation (GM-CSF) [103]. Camel eosinophils are also effective killers of parasites by their prominent cytoplasmic granules, which contain toxic molecules and enzymes that are particularly active against helminths and other parasites. It is not yet clear how these structural differences render the camel with such an apparent efficiency for killing parasites [87] [88] [103].

Mast cells, basophils and eosinophils that have been stimulated by IgE release substantial amounts of inteleukin-4 (IL-4) and histamine, suggesting that they can play important role in the induction of allergic responses [88] [97].

Natural killer cells (NKs) have been described in camels. They are involved primarily in innate immune responses against intracellular pathogens and tu- 
mour cells. NKs are characterized by an absence of TCR or surface immunoglobulin (Ig). However, NKs could influence adaptive immune responses via the production of cytokines [88] [93]. The recruited NKs to the site of an infection are activated by type-I interferons (IFN- $\alpha / \beta)$ produced by infected cells. IL-12, TNF- $\alpha$ and interleukin-18 (IL-18) produced by activated macrophages and DCs are important for NKs maturation and their production of IFN- $\gamma$, whereas interleukin-15 (IL-15) is important for the survival and proliferation of immature NKs [95].

\subsection{Camel Immune Responses to Certain Infectious Diseases}

The research history of camel infectious diseases has shown that camels are important sources of zoonotic diseases [105]. Camels have expressed significant resistance to certain infectious diseases [91], whereas they are susceptible to infections of viral, bacterial and protozoan pathogens [106]. Here we discuss selected viral, bacterial and parasitic diseases in camels to elaborate the most effective immune responses.

\subsubsection{Viral Infections: Middle East Respiratory Syndrome Coronavirus (MERS-CoV)}

The camel was identified as a source of the new viral disease spillover which emerged in 2012 in Saudi Arabia. The Middle East respiratory syndrome coronavirus (MERS-CoV) was caused by a novel coronavirus infection which was suspected to have begun in camels [107]. The infection causes severe acute respiratory disease [105] and may demonstrate nasal discharge and transient respiratory symptoms [108]. Notably, a very high seropositive rate, exceeding $90 \%$ in the camel population in the Middle East and in sub-Saharan African countries [109]. The dipeptidyl peptidase 4 (DPP4) (CD26) in the upper respiratory tract epithelium was identified as the prime receptor for the attachment of MERS-CoV [108]. This may help explain the restriction of the MERS-CoV replication to the upper respiratory tract [108]. Seropositive MERS-CoV dromedary camels may carry MERS-CoV viral RNA in their nasal excretions [108].

Few studies have explored the humoral immune response during MERS-CoV infection in dromedary camels. Unfortunately, to date, studies of the CMI response to the MERS-CoV infection are unavailable. Immunity against MERS-CoV in camels could share certain aspects of immune responses to that of human responses to the infection. The infection involves both cellular and humoral responses. MERS-CoV has evolved strategies to suppress host innate antiviral responses by exaggerated inflammatory response, contributing to its pathogenesis [110]. Recent analysis of MERS-CoV in epithelial cells has indicated little detectable IFN or IFN-stimulated gene (ISG) expression, which could be attributable to the diminished immunity in early stages of infection [109]. However, serologic studies in camels have revealed the elevation of the anti-MERS-CoV neutralizing antibodies from 14 days post infection, reaching a maximum titre of 640 after 35 days [107]. 


\subsubsection{Bacterial Infections: Brucellosis}

Camelids are susceptible to both Brucella abortus and Brucella melitensis [111]. The major brucellosis symptoms in camels are orchitis, epididymitis, metritis, reduced fertility, and abortion [105]. Brucellosis in infected camels could be asymptomatic, behaving as a carrier without revealing detectable immune responses [112].

Clinical brucellosis in camels is associated with proinflammatory cytokines [113]. Inflammatory cytokines could be associated with endotoxemia. Camel infection is associated with the upregulation of the cytokines IL-6, IFN- $\gamma$, interleukin-10 (IL-10), interleukin- $1 \alpha$ and $\beta$ (IL- $\alpha$ and $\beta$ ) and the TNF- $\alpha$ [113] [114]. A study of camels infected with both Brucella abortus and Brucella melitensis revealed a significant increase of IL- $1 \beta$ and IL-10 and a significant decrease of TNF $\alpha$, IFN- $\gamma$ and IL- $1 \alpha$. The modulation of the cytokines in the infected camels was seen as an important brucella mechanism to evade an immune response [115]. Protective immunity as the result of infection or vaccination are dependent on the generation of IFN- $\gamma$ producing T-cells with no or low expression of IL-10 and interleukin-4 (IL-4) [113].

\subsubsection{Parasitic Infection: Trypanosomiasis}

Camel trypanosomiasis is one of the main causes of abortions in camels in the Middle East and Africa [116]. Trypanosoma evansi (T. evansi) is the most pathogenic protozoa of camels and causes severe disease known as surra [117]. T. evansi is transmitted mechanically by hematophagous flies such as horseflies (Tabanus) and stable flies (Stomoxys) [117]. T. evansi are extracellular parasites that survive, multiply and differentiate in the extracellular fluids of the mammalian host [117]. The whole parasite surface is covered with a glycoprotein coat called the variant surface glycoprotein (VSG) [118].

The symptoms are associated with significant reductions in the number of red blood cells (RBC), haemoglobin and packed cell volume (PCV) [116]. Outbreak of trypanosomiasis can lead to significant mortalities or abortions.

The most significant immune response to this protozoon is the activation of the classical complement pathway to control parasitaemia in camels. Immunity against $T$. evansi is also associated with activated macrophages by producing an enhanced amount of TNF- $\alpha$, IL-6, IL-12, and IL-10 [118]. Nevertheless, the infection could be associated with immunosuppression by decreasing the level of complement haemolytic activity by $\mathrm{C} 3$ activation induced by antigen-antibody complexes [103] [119] [120]. Furthermore, various studies have shown that $T$. evansi could be involved in the immunosuppression mechanism by polyclonal B-cell activation and generation of suppressor T-cells and altered antigen handling and presentation as well as production of large amounts of nonspecific IgM [121] [122].

The host's skin indicates an increased $\mathrm{CMI}$ response of $\mathrm{CD}^{+}, \mathrm{CD}^{+}, \mathrm{CD}^{+}$ and MHC-restricted lymphocytes and B cells [121]. Antigenic variation in the exposed membrane-surface glycoprotein of trypanosome is responsible for pro- 
duction of evading antibodies [117]. Hence, recurring waves of parasitaemia are eminent because several days are required to develop destructive specific antibodies to VSG of T. evansi [118].

\section{Immunodiagnosis of Camel Diseases}

Various diagnostic methods can be used, either alone or in combination with other methods, to reach an appropriate and accurate diagnosis. Although reliable diagnosis can be achieved by direct isolation and detection of the causative agent, this approach is laborious and associated with a high contamination and impracticality for regular screening on a large scale [123] [124].

Serology, or antigen-antibody interaction, is one of the most applied approaches to detect active infection. Serological techniques can be applied for the evaluation of specific antibodies (IgG and IgM) in animals, which they play a key role in rapid and appropriate diagnosis [125].

Serological tests are widely applied in the diagnosis of camel diseases. For instance, various tests can be done on camels for anti-Brucella antibodies. These tests include the Rose Bengal Test (RBT), the Serum Agglutination Test (SAT) and the Complement Fixation Test (CFT) are among the most useful tests for routine diagnosis. Sensitivity of the serological tests depends on the type of the disease-acute or chronic and stage of infection. In Brucella infection in camel, the sensitivity of the RBT is believed to be the optimum choice for surveillance at herd level. In contrast, it is believed that only a combination of the RBT and the CFT in infected herds can give accurate individual sensitivity test results [126]. Different serological diagnostic methods have been applied for the detection of camel diseases. The most applied of these techniques are as follows.

\subsection{The Microscopic Agglutination Test (MAT)}

This test is widely used for the diagnosis of Leptospirosis, a zoonotic disease that infects camels and other animals, including humans. Using the MAT, leptospiral identification varied from $20 \%$ to $32.4 \%$ and $6.33 \%$ to $22.85 \%$ [105] using polymerase chain reaction (PCR) [127]. However, in Saudi Arabia diagnosis of camel leptospirosis was carried out by the Plate Agglutination Test (PAT) with a sensitivity of 6.7\% [128]. Niloofa et al. (2015) stated that both IgM-ELISA and Leptocheck-western blotting (WB) have identical sensitivity [129]. They also found that IgM-ELISA may be superior to the MAT during the acute phase and suitable for early diagnosis of leptospirosis.

\subsection{The Modified Agglutination Test (MAT)}

The MAT is highly recommended for the diagnosis of Toxoplasmosis in camels and humans because of its easy procedure and low price. In addition, it has expressed the highest sensitivity compared to all the other serological tests, at $96 \%$ [130] [131]. 


\subsection{The Complement Fixation Test (CFT)}

The CFT is one of the most reliable serological techniques for detecting antigen-antibody reactions using complement system as an indicator. The CFT is used for the detection of foot and mouth disease (FMD) infection in camels. It may also be considered standard for virus diagnosis [132]. In camel brucellosis, the CFT indicated high seroposivity (98.98\%) in detection of the disease [133]. Khan et al. (2020) found that the CFT expressed a significant positive rate for detection of anti-Brucella antibodies compared to the ELISA test [134].

\subsection{Western Blotting (WB)}

WB can be used for the detection of low antibody concentration [135]. WB is also the test of choice for the identification of immunospecific proteins. Due to its high sensitivity and specificity, WB is considered a preferable choice as a decision-making tool in the field [136].

\subsection{Enzyme-Linked Immunosorbent Assays (ELISA)}

The most challenging requirement for the sereological test is its sensitivity and specificity to differentiate between infected from vaccinated cases [137]. ELISA was developed to achieve the upmost sensitivity and specificity in detection of antibody-antigen reactions. ELISA is an assay designed in different antigens or antibody combinations to increase the specificity of the test to measure the concentration or presence of antigens or antibodies. Based on different combinations of antigens and antibodies, there are three types of ELISA: indirect, sandwich and competitive ELISA [138].

ELISA is widely applied in the diagnosis of camel diseases. For instance, the indirect ELISA technique was used for the detection of adenovirus type 3 in camels [139]. The overall seroprevalence rate was about $90 \%$. Chlamydiosis is one the diseases that causes foetal death and abortion in camels. However, the indirect ELISA detection rate was $>40 \%$ in detection of anti-Chlamydia abortus antibodies [140]. The ELISA technique has proved its versatility to differentiate between orthopox and parapoxvirus infections in camels [141]. Moreover, a seropositivity rate of $70.8 \%$ of MERS-CoV antibodies was shown in a survey of seroprevalence of MERS-CoV in camels in slaughterhouses [142]. The early detection of the Mycobacterium avium subspecies paratuberculosis (MAP), which causes John's disease in camels, has faced challenges using conventional approaches. However, ELISA has shown reliability and sensitivity in the detection of the MAP infection in camel herds. Nevertheless, detection of the infection in the early stages needs to be enhanced by combining ELISA with PCR [13].

\section{Conclusions}

Camels form an integral part of the culture and agriculture of many people around the world. The camel's economy is of considerable importance particularly in arid countries. Camel milk and meat are considered important 
sources of proteins for a wide population. Study of the camel's immune system is vital for camel welfare by enhancing the control measures and the diagnostic tools that protect camels from developing infectious diseases. The anatomical and histological details of the camel's immune organs have shown a structure which differs from other ruminants, in particular the thymus, tonsils, and PP. However, the immune mechanisms orchestrated by these organs are yet to be discovered. Despite numerous publications on camel immune cells, wide gaps still exist in the literature as to their role and the mechanisms driving the immune responses. The CMI, the role of the MHC in restricting the cellular immune responses, awaits to complete the picture of the regulatory roles of the camel's MHC-1 and II genes. Our understanding of the factors involved in innate immunity, such as PRRs and other soluble factors, is now clearer, particularly that of camel milk. However, the role the innate factors play in paving the way to adaptive immunity requires more explicit research. Successful measures to control fatal camel diseases are hindered by the lack of appropriate diagnostic tests that embed the specific camel antibodies. Nevertheless, tests with xenogeneic antibodies have been relatively effective in the diagnosis of certain camel diseases.

In conclusion, research in the field of the camel immune system is slow and has attracted slow academic attention. However, so far important findings have been made. The major setbacks that hinder the research are, first is the unavailability or poor production of reagents that would enable detailed study of the camel's immune system. Research in camel immune system to be boosted considerably requires allocation of sufficient budgets to meet the need of explicit and extensive research as well as founding major international scientific communities and societies that encourage the research in this field and act as forecasting bodies that contribute to the research perspective in this field.

\section{Data Availability Statement}

This review article is based on the published available literature. Otherwise, published were authorized by the corresponding authors.

\section{Ethics Statement}

The review was carried out according to International Guidelines for research involving animals (Directive 2010/63/EU).

\section{Authors' Contributions}

All authors listed have made a substantial, direct, and intellectual contribution to the work, and approved it for publication.

\section{Acknowledgments}

The authors would like to acknowledge all colleagues who offered advice, assistance and directions in preparing this manuscript and its organization. 


\section{Conflicts of Interest}

The authors declare no conflicts of interest regarding the publication of this paper.

\section{References}

[1] Khalaf, S. (1999) Camel Racing in the Gulf. Notes on the Evolution of a Traditional Cultural Sport. Anthropos, 94, 85-106.

[2] Abri, M.A.A. and Faye, B. (2019) Genetic Improvement in Dromedary Camels: Challenges and Opportunities. Frontiers in Genetics, 10, 167. https://doi.org/10.3389/fgene.2019.00167

[3] Sharma, C. and Singh, C. (2014) Therapeutic Value of Camel Milk-A Review. Advanced Journal of Pharmacy and Life Science Research, 2, 7-13.

[4] Bekele, T., Lundeheim, N. and Dahlborn, K. (2011) Milk Production and Feeding Behavior in the Camel (Camelus dromedarius) during 4 Watering Regimens. Journal of Dairy Science, 94, 1310-1317. https://doi.org/10.3168/jds.2010-3654

[5] Breulmann, M., Böer, B., Wernery, U., Wernery, R., El Shaer, H., Alhadrami, G., Gallacher, D., Peacock, J., Chaudhary, A. and Brown, G. (2007) The Camel from Tradition to Modern Times. The United Nations Educational, Scientific and Cultural Organization Office, Doha, 21-24.

[6] Rao, M.B., Gupta, R.C. and Dastur, N.N. (1970) Camels' Milk and Milk Products. Indian Journal of Dairy Science, 23, 71-78.

[7] El-Hatmi, H., Girardet, J.-M., Gaillard, J.-L., Yahyaoui, M.H. and Attia, H. (2007) Characterisation of Whey Proteins of Camel Camelus dromedarius Milk and Colostrum. Small Ruminant Research, 70, 267-271. https://doi.org/10.1016/j.smallrumres.2006.04.001

[8] Ramet, J.-P. (2001) The Technology of Making Cheese from Camel Milk (Camelus dromedarius). Food \& Agriculture Org.

[9] Faye, B. and Bonnet, P. (2012) Camel Sciences and Economy in the World: Current Situation and Perspectives. 29 th ISOCARD Conference, 3 January-1 February 2012, 2-15.

[10] Kadim, I., Mahgoub, O. and Purchas, R. (2008) A Review of the Growth, and of the Carcass and Meat Quality Characteristics of the One-Humped Camel (Camelus dromedarius). Meat Science, 80, 555-569. https://doi.org/10.1016/j.meatsci.2008.02.010

[11] Abbas, B. and Agab, H. (2002) A Review of Camel Brucellosis. Preventive Veterinary Medicine, 55, 47-56. https://doi.org/10.1016/S0167-5877(02)00055-7

[12] Abbas, B. and Omer, O. (2005) Review of Infectious Diseases of the Camel. Veterinary Bulletin, 75, 1-16. https://doi.org/10.4236/ojvm.2015.57021

[13] Alluwaimi, A.M. (2015) Paratuberculosis Infection in Camel (Camelus dromedarius): Current and Prospective Overview. Open Journal of Veterinary Medicine, 5, 153.

[14] Parsani, H., Singh, V. and Momin, R. (2008) Common Parasitic Diseases of Camel. Vet World, 1, 317-318.

[15] Dudas, G., Carvalho, L.M., Rambaut, A. and Bedford, T. (2018) Mers-Cov Spillover at the Camel-Human Interface. Elife, 7, e31257. https://doi.org/10.7554/eLife.37324

[16] Zhu, S., Zimmerman, D. and Deem, S.L. (2019) A Review of Zoonotic Pathogens of Dromedary Camels. Ecohealth, 16, 356-377. 
https://doi.org/10.1007/s10393-019-01413-7

[17] Schuberth, H.-J. and Hussen, J. (2020) Recent Advances in Camel Immunology. Frontiers in Immunology, 11, 3569. https://doi.org/10.3389/fimmu.2020.614150

[18] Al-Ramadan, S., SALEM, K.A.-M., Alshubaith, I. and Alluwaimi, A. (2020) Cd Markers of Camel (Camelus dromedarius) Intestine Naturally Infected with Mycobacterium Avium Subsp. Paratuberculosis: Distinct Expression of Madcam-1 and Cx3cr1. Turkish Journal of Veterinary and Animal Sciences, 44, 1010-1023. https://doi.org/10.3906/vet-2003-5

[19] Al-Ramadan, S.Y. and Alluwaimi, A.M. (2018) The Lymphoid Tissue in the Palatine Tonsils of the Dromedary Camel (Camelus dromedarius). Journal of Camel Practice and Research, 25, 65-73. https://doi.org/10.5958/2277-8934.2018.00010.3

[20] Aly, A. (1986) Some Anatomical Studies on the Camel's Thymus (Camelus dromedarius). Zagazig Veterinary Journal, 13, 34-46.

[21] Smuts, M.M.S. and Bezuidenhout, A.J. (1987) Anatomy of the Dromedary. Oxford University Press, Oxford.

[22] Jarrar, B. and Faye, B. (2013) Normal Pattern of Camel Histology. FAO Publications, Riyadh.

[23] Ismail, H. and Ali, A. (2015) Immunohistochemical Studies on the Endocrine Cells in the Thymus of the One-Humped-Camel (Camelus dromedarius). Journal of Camel Practice and Research, 22, 251-256.

https://doi.org/10.5958/2277-8934.2015.00041.7

[24] Nazifi, S., Tadjalli, M. and Bedeltavana, A. (1998) Normal Haematopoiesis, Cellular Components and Stainable Iron Content in the Bone Marrow of Camels (Camelus dromedarius). Veterinary Research Communications, 22, 11-20. https://doi.org/10.1023/A:1005979010229

[25] ZhaXi, Y., Wang, W., Zhang, W., Gao, Q., Guo, M. and Jia, S. (2014) Morphologic Observation of Mucosa-Associated Lymphoid Tissue in the Large Intestine of Bactrian Camels (Camelus bactrianus). The Anatomical Record, 297, 1292-1301. https://doi.org/10.1002/ar.22939

[26] He, W., Zhang, W., Cheng, C., Li, J., Wu, X., Li, M., Chen, Z. and Wang, W. (2019) The Distributive and Structural Characteristics of Bronchus-Associated Lymphoid Tissue (Balt) in Bactrian Camels (Camelus bactrianus). PeerJ, 7, e6571. https://doi.org/10.7717/peerj.6571

[27] Achaaban, M., Mouloud, M., Tligui, N. and El Allali, K. (2016) Main Anatomical and Histological Features of the Tonsils in the Camel (Camelus dromedarius). Tropical Animal Health and Production, 48, 1653-1659. https://doi.org/10.1007/s11250-016-1139-x

[28] Zidan, M. and Pabst, R. (2009) The Microanatomy of the Palatine Tonsils of the One-Humped Camel (Camelus dromedarius). The Anatomical Record, 292, 1192-1197. https://doi.org/10.1002/ar.20948

[29] Zidan, M. and Pabst, R. (2019) Histological Characterization of the Lingual Tonsils of the One-Humped Camel (Camelus dromedarius). Cell and Tissue Research, 1-7. https://doi.org/10.1007/s00441-019-03135-2

[30] Achaaban, M., Mouloud, M., Tligui, N. and El Allali, K. (2013) The Camel Soft Palate Diverticulum: Structure and Mechanism of Its Oral Exteriorisation. 1 st International Conference on Sustainability of Camel Population and Production, Al-Ahsa, Saudi Arabia, 18 February 2013, 27-31.

[31] El-Bab, M., Ali, A., Alluwaimi, A., Ahmed, A. and Saad, A. (2000) Alkaline and Ac- 
id Phosphatase Reactivity of the Ileal Peyer's Patches in Camels (Camelus dromedarius). Journal of Camel Practice and Research, 7, 175-179.

[32] Zidan, M. and Pabst, R. (2008) Unique Microanatomy of Ileal Peyer's Patches of the One Humped Camel (Camelus dromedarius) Is Not Age-Dependent. The Anatomical Record, 291, 1023-1028. https://doi.org/10.1002/ar.20697

[33] Zidan, M. and Pabst, R. (2012) Histological, Histochemical and Immunohistochemical Study of the Lymph Nodes of the One Humped Camel (Camelus dromedarius). Veterinary Immunology and Immunopathology, 145, 191-198. https://doi.org/10.1016/j.vetimm.2011.11.004

[34] Gavrilin, P., Gavrilina, O., Brygadyrenko, V. and Rahmoun, D. (2017) Structural and Functional Units of Parenchyma of Lymph Nodes of Dromedaries (Camelus dromedarius). Regulatory Mechanisms in Biosystems, 8, 232-333.

https://doi.org/10.15421/021751

[35] Abdel-Magied, E., Taha, A., Al-Qarawi, A. and Elfaki, M. (2001) The Parotid, Mandibular and Lateral Retropharyngeal Lymph Nodes of the Camel (Camelus dromedarius). Anatomia, Histologia, Embryologia, 30, 199-203.

https://doi.org/10.1046/j.1439-0264.2001.00308.x

[36] Alshamarry, H.A. (2010) Histological and Histometric Study on the Spleen of Iraqi Camel (Camelus dromedarius). Emirates Journal of Food and Agriculture, 22, 65-70. https://doi.org/10.9755/ejfa.v22i1.4908

[37] Maina, M., Usende, I., Igwenagu, E., Onyiche, T., Yusuf, Z. and Ntung, N. (2014) Gross, Histological and Histomorphometric Studies on the Spleen of One Humped Camel (Camelus dromedarius) Found in the Semi-Arid Region of North Eastern Nigeria. Journal of Veterinary Advances, 4, 703-711. https://doi.org/10.5455/jva.20141025045543

[38] Zidan, M., Kasse, A., Dougbag, A., El Ghazzawi, E., El Aziz, M.A. and Pabst, R. (2000) The Spleen of the One Humped Camel (Camelus dromedarius) Has a Unique Histological Structure. Journal of Anatomy, 196, 425-432. https://doi.org/10.1046/j.1469-7580.2000.19630425.x

[39] Zidan, M., Schuberth, H. and Pabst, R. (2000) Immunohistology of the Splenic Compartments of the One Humped Camel (Camelus dromedarius). Veterinary Immunology and Immunopathology, 74, 17-29. https://doi.org/10.1016/S0165-2427(00)00153-7

[40] Janeway, C.A., Travers, P., Walport, M. and Shlomchik, M. (2001) Immunobiology. Garland Science, New York and London.

[41] De Genst, E., Saerens, D., Muyldermans, S. and Conrath, K. (2006) Antibody Repertoire Development in Camelids. Developmental \& Comparative Immunology, 30, 187-198. https://doi.org/10.1016/j.dci.2005.06.010

[42] Conrath, K., Wernery, U., Muyldermans, S. and Nguyen, V. (2003) Emergence and Evolution of Functional Heavy-Chain Antibodies in Camelidae. Developmental \& Comparative Immunology, 27, 87-103. https://doi.org/10.1016/S0145-305X(02)00071-X

[43] Griffin, L.M., Snowden, J.R., Lawson, A.D., Wernery, U., Kinne, J. and Baker, T.S. (2014) Analysis of Heavy and Light Chain Sequences of Conventional Camelid Antibodies from Camelus dromedarius and Camelus bactrianus Species. Journal of Immunological Methods, 405, 35-46. https://doi.org/10.1016/j.jim.2014.01.003

[44] Zhao, Y., Jackson, S.M. and Aitken, R. (2006) The Bovine Antibody Repertoire. Developmental \& Comparative Immunology, 30, 175-186.

https://doi.org/10.1016/j.dci.2005.06.012 
[45] Zhang, W.-D., Wang, W.-H. and Jia, S. (2015) Distribution of Immunoglobulin G Antibody Secretory Cells in Small Intestine of Bactrian Camels (Camelus bactrianus). BMC Veterinary Research, 11, 1-8. https://doi.org/10.1186/s12917-015-0538-y

[46] Zhang, W.-D., Wang, W.-H. and Jia, S. (2016) The Distribution of Siga and Igg Antibody-Secreting Cells in the Small Intestine of Bactrian Camels (Camelus bactrianus) of Different Ages. PLoS ONE, 11, e0156635.

https://doi.org/10.1371/journal.pone.0156635

[47] Steeland, S., Vandenbroucke, R.E. and Libert, C. (2016) Nanobodies as Therapeutics: Big Opportunities for Small Antibodies. Drug Discovery Today, 21, 1076-1113. https://doi.org/10.1016/j.drudis.2016.04.003

[48] Papadopoulos, K.P., Isaacs, R., Bilic, S., Kentsch, K., Huet, H.A., Hofmann, M., Rasco, D., Kundamal, N., Tang, Z., Cooksey, J. and Mahipal, A. (2015) Unexpected Hepatotoxicity in a Phase I Study of Tas266, a Novel Tetravalent Agonistic Nanobody ${ }^{\oplus}$ Targeting the Dr5 Receptor. Cancer Chemotherapy and Pharmacology, 75, 887-895. https://doi.org/10.1007/s00280-015-2712-0

[49] Ingram, J.R., Schmidt, F.I. and Ploegh, H.L. (2018) Exploiting Nanobodies' Singular Traits. Annual Review of Immunology, 36, 695-715. https://doi.org/10.1146/annurev-immunol-042617-053327

[50] Pinto Torres, J.E., Goossens, J., Ding, J., Li, Z., Lu, S., Vertommen, D., Naniima, P., Chen, R., Muyldermans, S., Sterckx, Y.G.J. and Magez, S. (2018) Development of a Nanobody-Based Lateral Flow Assay to Detect Active Trypanosoma Congolense Infections. Scientific Reports, 8, 9019. https://doi.org/10.1038/s41598-018-26732-7

[51] Tu, Z., Chen, Q., Li, Y., Xiong, Y., Xu, Y., Hu, N. and Tao, Y. (2016) Identification and Characterization of Species-Specific Nanobodies for the Detection of Listeria Monocytogenes in Milk. Analytical Biochemistry, 493, 1-7. https://doi.org/10.1016/j.ab.2015.09.023

[52] Zafra, O., Fraile, S., Gutiérrez, C., Haro, A., Páez-Espino, A.D., Jiménez, J.I. and de Lorenzo, V. (2011) Monitoring Biodegradative Enzymes with Nanobodies Raised in Camelus dromedarius with Mixtures of Catabolic Proteins. Environmental Microbiology, 13, 960-974. https://doi.org/10.1111/j.1462-2920.2010.02401.x

[53] Alvarez-Rueda, N., Behar, G., Ferré, V., Pugnière, M., Roquet, F., Gastinel, L., Jacquot, C., Aubry, J., Baty, D., Barbet, J. and Birklé, S. (2007) Generation of Llama Single-Domain Antibodies against Methotrexate, a Prototypical Hapten. Molecular Immunology, 44, 1680-1690. https://doi.org/10.1016/j.molimm.2006.08.007

[54] Iezzi, M.E., Policastro, L., Werbajh, S., Podhajcer, O. and Canziani, G.A. (2018) Single-Domain Antibodies and the Promise of Modular Targeting in Cancer Imaging and Treatment. Frontiers in Immunology, 9, 273.

https://doi.org/10.3389/fimmu.2018.00273

[55] Salvador, J.P., Vilaplana, L. and Marco, M.P. (2019) Nanobody: Outstanding Features for Diagnostic and Therapeutic Applications. Analytical and Bioanalytical Chemistry, 411, 1703-1713. https://doi.org/10.1007/s00216-019-01633-4

[56] Klooster, R., Maassen, B.T., Stam, J.C., Hermans, P.W., Mark, R., Detmers, F.J., de Haard, H.J., Post, J.A. and Verrips, C.T. (2007) Improved Anti-Igg and Hsa Affinity Ligands: Clinical Application of Vhh Antibody Technology. Journal of Immunological Methods, 324, 1-12. https://doi.org/10.1016/j.jim.2007.04.005

[57] Ibañez, L.I., De Filette, M., Hultberg, A., Verrips, T., Temperton, N., Weiss, R.A., Vandevelde, W., Schepens, B., Vanlandschoot, P. and Saelens, X. (2011) Nanobodies with in Vitro Neutralizing Activity Protect Mice against H5n1 Influenza Virus Infection. The Journal of Infectious Diseases, 203, 1063-1072. 
https://doi.org/10.1093/infdis/jiq168

[58] Unger, M., Eichhoff, A.M., Schumacher, L., Strysio, M., Menzel, S., Schwan, C., Alzogaray, V., Zylberman, V., Seman, M., Brandner, J., Rohde, H., Zhu, K., Haag, F., Mittrücker, H.-W., Goldbaum, F., Aktories, K. and Koch-Nolte, F. (2015) Selection of Nanobodies That Block the Enzymatic and Cytotoxic Activities of the Binary Clostridium Difficile Toxin Cdt. Scientific Reports, 5, Article No. 7850. https://doi.org/10.1038/srep07850

[59] Van Heeke, G., Allosery, K., De Brabandere, V., De Smedt, T., Detalle, L. and de Fougerolles, A. (2017) Nanobodies ${ }^{\circledast}$ as Inhaled Biotherapeutics for Lung Diseases. Pharmacology and Therapeutics, 169, 47-56. https://doi.org/10.1016/j.pharmthera.2016.06.012

[60] Lafaye, P., Achour, I., England, P., Duyckaerts, C. and Rougeon, F. (2009) Single-Domain Antibodies Recognize Selectively Small Oligomeric Forms of Amyloid $B$, Prevent A $\beta$-Induced Neurotoxicity and Inhibit Fibril Formation. Molecular Immunology, 46, 695-704. https://doi.org/10.1016/j.molimm.2008.09.008

[61] Vuchelen, A., O’Day, E., De Genst, E., Pardon, E., Wyns, L., Dumoulin, M., Dobson, C.M., Christodoulou, J. and Hsu, S.-T.D. (2009) 1h, 13c and 15n Assignments of a Camelid Nanobody Directed against Human A-Synuclein. Biomolecular NMR Assignments, 3, 231. https://doi.org/10.1007/s12104-009-9182-4

[62] Wang, Y., Fan, Z., Shao, L., Kong, X., Hou, X., Tian, D., Sun, Y., Xiao, Y. and Yu, L. (2016) Nanobody-Derived Nanobiotechnology Tool Kits for Diverse Biomedical and Biotechnology Applications. International Journal of Nanomedicine, 11, 3287-3303. https://doi.org/10.2147/IJN.S107194

[63] Abulrob, A., Sprong, H., En Henegouwen, P.V.B. and Stanimirovic, D. (2005) The Blood-Brain Barrier Transmigrating Single Domain Antibody: Mechanisms of Transport and Antigenic Epitopes in Human Brain Endothelial Cells. Journal of Neurochemistry, 95, 1201-1214. https://doi.org/10.1111/j.1471-4159.2005.03463.x

[64] Fraser, G., Smith, C.A., Imrie, K., Meyer, R. and Hematology Disease Site Group of Cancer Care Ontario's Program in Evidence-Based, C. (2007) Alemtuzumab in Chronic Lymphocytic Leukemia. Current Oncology (Toronto, Ont), 14, 96-109. https://doi.org/10.3747/co.2007.118

[65] Harmsen, M.M., van Solt, C.B., van Zijderveld-van Bemmel, A.M., Niewold, T.A. and van Zijderveld, F.G. (2006) Selection and Optimization of Proteolytically Stable Llama Single-Domain Antibody Fragments for Oral Immunotherapy. Applied Microbiology and Biotechnology, 72, 544-551. https://doi.org/10.1007/s00253-005-0300-7

[66] Chan, J., Ng, C. and Hui, P. (1988) A Simple Guide to the Terminology and Application of Leucocyte Monoclonal Antibodies. Histopathology, 12, 461-480. https://doi.org/10.1111/j.1365-2559.1988.tb01967.x

[67] Ordóñez, N.G. (2012) Immunohistochemical Endothelial Markers: A Review. Advances in Anatomic Pathology, 19, 281-295. https://doi.org/10.1097/PAP.0b013e3182691c2a

[68] Hodgkinson, A., Carpenter, E.A., Smith, C., Molan, P.C. and Prosser, C.G. (2007) Adhesion Molecule Expression in the Bovine Mammary Gland. Veterinary Immunology and Immunopathology, 115, 205-215. https://doi.org/10.1016/j.vetimm.2006.10.020

[69] Nishimura, T. (2003) Expression of Potential Lymphocyte Trafficking Mediator Molecules in the Mammary Gland. Veterinary Research, 34, 3-10.

https://doi.org/10.1051/vetres:2002045 
[70] Van der Feltz, M., De Groot, N., Bayley, J.P., Lee, S., Verbeet, M.P. and De Boer, H. (2001) Lymphocyte Homing and Ig Secretion in the Murine Mammary Gland. Scandinavian Journal of Immunology, 54, 292-300. https://doi.org/10.1046/j.1365-3083.2001.00933.x

[71] Sordillo, L.M. and Streicher, K.L. (2002) Mammary Gland Immunity and Mastitis Susceptibility. Journal of Mammary Gland Biology and Neoplasia, 7, 135-146. https://doi.org/10.1023/A:1020347818725

[72] Hughes, C.E. and Nibbs, R.J. (2018) A Guide to Chemokines and Their Receptors. The FEBS Journal, 285, 2944-2971. https://doi.org/10.1111/febs.14466

[73] Hussen, J., Shawaf, T., Al-herz, A.I., Alturaifi, H.R. and Alluwaimi, A.M. (2017) Reactivity of Commercially Available Monoclonal Antibodies to Human Cd Antigens with Peripheral Blood Leucocytes of Dromedary Camels (Camelus dromedarius). Open Veterinary Journal, 7, 150-156. https://doi.org/10.4314/ovj.v7i2.12

[74] Al-Mohammed Salem, K.T., Al Ramadan, S.Y. and Alluwaimi, A.M. (2012) Adhesion Molecules and the Cellular Population of the Normal Camel (Camelus dromedarius) Mammary Glands. The Open Veterinary Science Journal, 6, 15-22. https://doi.org/10.2174/1874318801206010015

[75] Davis, W.C., Drbal, K., Abdel-El-Aziz, A., Elbagory, A.-R.M., Tibary, A., Barrington, G.M., Park, Y.H. and Hamilton, M.J. (2007) Use of Flow Cytometry to Identify Monoclonal Antibodies That Recognize Conserved Epitopes on Orthologous Leukocyte Differentiation Antigens in Goats, Lamas, and Rabbits. Veterinary Immunology and Immunopathology, 119, 123-130. https://doi.org/10.1016/j.vetimm.2007.06.024

[76] Hussen, J., Shawaf, T., Al-herz, A.I., Alturaifi, H.R. and Alluwaimi, A.M. (2018) Expression Patterns of Cell Adhesion Molecules on Cd4+ T Cells and Wc1 + T Cells in the Peripheral Blood of Dromedary Camels. Pakistan Veterinary Journal, 38, 231-236. https://doi.org/10.29261/pakvetj/2018.055

[77] Gaashan, M.M., Al-Mubarak, A.I. and Hussen, J. (2020) Leukocyte Populations and Their Cell Adhesion Molecules Expression in Newborn Dromedary Camel Calves. Veterinary World, 13, 1863. https://doi.org/10.14202/vetworld.2020.1863-1869

[78] Alluwaimi, A. and Cullor, J.S. (2002) Cytokines Gene Expression Patterns of Bovine Milk during Middle and Late Stages of Lactation. Journal of Veterinary Medicine, Series B, 49, 105-110. https://doi.org/10.1046/j.1439-0450.2002.00515.x

[79] Hussen, J., Shawaf, T., Al-Mubarak, A.I., Al Humam, N.A., Almathen, F. and Schuberth, H.-J. (2020) Dromedary Camel Cd14 High Mhcii High Monocytes Display Inflammatory Properties and Are Reduced in Newborn Camel Calves. BMC Veterinary Research, 16, 1-10. https://doi.org/10.1186/s12917-020-02285-8

[80] Hussen, J., Shawaf, T., Al-Mubarak, A.I., Al Humam, N.A., Almathen, F. and Schuberth, H.-J. (2020) Leukocyte Populations in Peripheral Blood of Dromedary Camels with Clinical Endometritis. Animal Reproduction Science, 222, Article ID: 106602. https://doi.org/10.1016/j.anireprosci.2020.106602

[81] Al-Ashqar, R.A., Salem, K.M.A.-M., Al Herz, A.K.M., Al-Haroon, A.I. and Alluwaimi, A.M. (2015) The Cd Markers of Camel (Camelus dromedarius) Milk Cells during Mastitis: The Lpam-1 Expression Is an Indication of Possible Mucosal Nature of the Cellular Trafficking. Research in Veterinary Science, 99, 77-81. https://doi.org/10.1016/j.rvsc.2015.01.011

[82] Lee, E. and Kehrli, M. (1998) Expression of Adhesion Molecules on Neutrophils of Periparturient Cows and Neonatal Calves. American Journal of Veterinary Research, 59, 37-43. 
[83] Engelhardt, B. (2007) A4-Integrins: Structure, Function and Secrets. In: Ley, K., Ed., Adhesion Molecules. Function and Inhibition, Springer, Berlin, 117-139. https://doi.org/10.1007/978-3-7643-7975-9_5

[84] Kehrli Jr., M.E. and Harp, J.A. (2001) Immunity in the Mammary Gland. The Veterinary Clinics of North America Food Animal Practice, 17, 495-516. https://doi.org/10.1016/S0749-0720(15)30003-7

[85] Regoli, M., Bertelli, E., Gulisano, M. and Nicoletti, C. (2017) The Multifaceted Personality of Intestinal Cx3cr1+ Macrophages. Trends in Immunology, 38, 879-886. https://doi.org/10.1016/j.it.2017.07.009

[86] Wilkie, B. (1974) Review of Bovine Immunology for the Veterinary Practitioner. The Canadian Veterinary Journal, 15, 243.

[87] Hendawy, S.H. (2018) Immunity to Gastrointestinal Nematodes in Ruminants: Effector Cell Mechanisms and Cytokines. Journal of Parasitic Diseases, 42, 471-482. https://doi.org/10.1007/s12639-018-1023-x

[88] Chaplin, D.D. (2010) Overview of the Immune Response. Journal of Allergy and Clinical Immunology, 125, S3-S23. https://doi.org/10.1016/j.jaci.2009.12.980

[89] Meyer, B., Juhasz, J., Barua, R., Gupta, A.D., Hakimuddin, F., Corman, V.M., Müller, M.A., Wernery, U., Drosten, C. and Nagy, P. (2016) Time Course of Mers-Cov Infection and Immunity in Dromedary Camels. Emerging Infectious Diseases, 22, 2171. https://doi.org/10.3201/eid2212.160382

[90] Al-Ruwaili, M.A., Khalil, O.M. and Selim, S.A. (2012) Viral and Bacterial Infections Associated with Camel (Camelus dromedarius) Calf Diarrhea in North Province, Saudi Arabia. Saudi Journal of Biological Sciences, 19, 35-41. https://doi.org/10.1016/j.sjbs.2011.10.001

[91] Plasil, M., Mohandesan, E., Fitak, R.R., Musilova, P., Kubickova, S., Burger, P.A. and Horin, P. (2016) The Major Histocompatibility Complex in Old World Camelids and Low Polymorphism of Its Class II Genes. BMC Genomics, 17, 167. https://doi.org/10.1186/s12864-016-2500-1

[92] Ciccarese, S., Burger, P.A., Ciani, E., Castelli, V., Linguiti, G., Plasil, M., Massari, S., Horin, P. and Antonacci, R. (2019) The Camel Adaptive Immune Receptors Repertoire as a Singular Example of Structural and Functional Genomics. Frontiers in Genetics, 10, 997. https://doi.org/10.3389/fgene.2019.00997

[93] Futas, J., Oppelt, J., Jelinek, A., Elbers, J.P., Wijacki, J., Knoll, A., Burger, P.A. and Horin, P. (2019) Natural Killer Cell Receptor Genes in Camels: Another Mammalian Model. Frontiers in Genetics, 10, 620. https://doi.org/10.3389/fgene.2019.00620

[94] Ungar-Waron, H., Yagil, R., Brenner, J., Paz, R., Partosh, N., Van Creveld, C., Lubashevsky, E. and Trainin, Z. (2003) Reactions of Peripheral Blood Mononuclear Cells (Pbmc) of Camels with Monoclonal Antibodies against Ruminant Leukocytes. Comparative Immunology, Microbiology and Infectious Diseases, 26, 137-143. https://doi.org/10.1016/S0147-9571(02)00037-1

[95] Corradi, A., Ferrari, L. and Borghetti, P. (2007) Parameters for Evaluating the Cell-Mediated Immune Response during Viral Infection: Diagnostic and Prognostic Applications. Veterinary Research Communications, 31, 103-107. https://doi.org/10.1007/s11259-007-0075-7

[96] Rouse, B.T. and Sehrawat, S. (2010) Immunity and Immunopathology to Viruses: What Decides the Outcome? Nature Reviews Immunology, 10, 514-526. https://doi.org/10.1038/nri2802

[97] Zimmerman, L., Vogel, L. and Bowden, R. (2010) Understanding the Vertebrate Immune System: Insights from the Reptilian Perspective. Journal of Experimental 
Biology, 213, 661-671. https://doi.org/10.1242/jeb.038315

[98] McRae, K.M., Stear, M.J., Good, B. and Keane, O.M. (2015) The Host Immune Response to Gastrointestinal Nematode Infection in Sheep. Parasite Immunology, 37, 605-613. https://doi.org/10.1111/pim.12290

[99] Netea, M.G., Van der Graaf, C., Van der Meer, J.W. and Kullberg, B.J. (2004) Toll-Like Receptors and the Host Defense against Microbial Pathogens: Bringing Specificity to the Innate-Immune System. Journal of Leukocyte Biology, 75, 749-755. https://doi.org/10.1189/jlb.1103543

[100] Arango Duque, G. and Descoteaux, A. (2014) Macrophage Cytokines: Involvement in Immunity and Infectious Diseases. Frontiers in Immunology, 5, 491.

https://doi.org/10.3389/fimmu.2014.00491

[101] Werling, D., Piercy, J. and Coffey, T.J. (2006) Expression of Toll-Like Receptors (Tlr) by Bovine Antigen-Presenting Cells-Potential Role in Pathogen Discrimination? Veterinary Immunology and Immunopathology, 112, 2-11. https://doi.org/10.1016/j.vetimm.2006.03.007

[102] Allam, T.S., Saleh, N.S., Abo-Elnaga, T.R. and Darwish, A.A. (2017) Cytokine Response and Immunological Studies in Camels (Camelus dromedarius) with Respiratory Diseases at Matrouh Province. Alexandria Journal for Veterinary Sciences, 53, 116-124. https://doi.org/10.5455/ajvs.259788

[103] Johnson, E.H., Al-Habsi, K.R. and Al-Busaidi, R.M. (2013) A Review of Observations Made on Select Parameters of the Camel Immune System. Journal of Agricultural and Marine Sciences, 18, 1-6. https://doi.org/10.24200/jams.vol18iss0pp1-6

[104] Wellnitz, O. and Bruckmaier, R.M. (2012) The Innate Immune Response of the Bovine Mammary Gland to Bacterial Infection. Veterinary Journal, 192, 148-152. https://doi.org/10.1016/j.tvjl.2011.09.013

[105] Mohammadpour, R., Champour, M., Tuteja, F. and Mostafavi, E. (2020) Zoonotic Implications of Camel Diseases in Iran. Veterinary Medicine and Science, 6, 359-381. https://doi.org/10.1002/vms3.239

[106] Kebede, F. and Gelaye, E. (2010) Studies on Major Respiratory Diseases of Camel (Camelus dromedarius) in Northeastern Ethiopia. African Journal of Microbiology Research, 4, 1560-1564.

[107] Adney, D.R., van Doremalen, N., Brown, V.R., Bushmaker, T., Scott, D., de Wit, E., Bowen, R.A. and Munster, V.J. (2014) Replication and Shedding of Mers-Cov in Upper Respiratory Tract of Inoculated Dromedary Camels. Emerging Infectious Diseases, 20, 1999. https://doi.org/10.3201/eid2012.141280

[108] Haagmans, B.L., van den Brand, J.M., Raj, V.S., Volz, A., Wohlsein, P., Smits, S.L., Schipper, D., Bestebroer, T.M., Okba, N. and Fux, R. (2016) An Orthopoxvirus-Based Vaccine Reduces Virus Excretion after Mers-Cov Infection in Dromedary Camels. Science, 351, 77-81. https://doi.org/10.1126/science.aad1283

[109] Goldstein, S.A. and Weiss, S.R. (2017) Origins and Pathogenesis of Middle East Respiratory Syndrome-Associated Coronavirus: Recent Advances. F1000Research, 6, 1628. https://doi.org/10.12688/f1000research.11827.1

[110] Banerjee, A., Subudhi, S., Rapin, N., Lew, J., Jain, R., Falzarano, D. and Misra, V. (2020) Selection of Viral Variants during Persistent Infection of Insectivorous Bat Cells with Middle East Respiratory Syndrome Coronavirus. Scientific Reports, 10, Article No. 7257. https://doi.org/10.1038/s41598-020-64264-1

[111] Benkirane, A., El Idrissi, A., Doumbia, A. and de Balogh, K. (2014) Innocuity and Immune Response to Brucella Melitensis Rev. 1 Vaccine in Camels (Camelus dromedarius). Open Veterinary Journal, 4, 96-102. 
[112] Dadar, M. and Alamian, S. (2020) Isolation of Brucella Melitensis from Seronegative Camel: Potential Implications in Brucellosis Control. Preventive Veterinary Medicine, 185, Article ID: 105194. https://doi.org/10.1016/j.prevetmed.2020.105194

[113] Odbileg, R., Purevtseren, B., Gantsetseg, D., Boldbaatar, B., Buyannemekh, T., Galmandakh, Z., Erdenebaatar, J., Konnai, S., Onuma, M. and Ohashi, K. (2008) Cytokine Responses in Camels (Camelus bactrianus) Vaccinated with Brucella Abortus Strain 19 Vaccine. Journal of Veterinary Medical Science, 70, 197-201. https://doi.org/10.1292/jvms.70.197

[114] Al Ali, A., Al Haroon, A. and Alluwaimi, A. (2008) The Relation of the Cytokines and the Cd Markers to the Antibody Titers in Patients with Brucellosis. Research Journal of Microbiology, 3, 641-647. https://doi.org/10.3923/jm.2008.641.647

[115] El-Boshy, M., Abbas, H., El-Khodery, S. and Osman, S. (2009) Cytokine Response and Clinicopathological Findings in Brucella Infected Camels (Camelus dromedarius). Veterinarni Medicina, 54, 25-32. https://doi.org/10.17221/3044-VETMED

[116] Bennoune, O., Adili, N., Amri, K., Bennecib, L. and Ayachi, A. (2013) Trypanosomiasis of Camels (Camelus dromedarius) in Algeria: First Report. Veterinary Research Forum: An International Quarterly Journal, 4, 273-275.

[117] Eyob, E. and Matios, L. (2013) Review on Camel Trypanosomosis (Surra) Due to Trypanosoma Evansi: Epidemiology and Host Response. Journal of Veterinary Medicine and Animal Health, 5, 334-343.

[118] Bezie, M., Girma, M., Dagnachew, S., Tadesse, D. and Tadesse, G. (2014) African Trypanosomes: Virulence Factors, Pathogenicity and Host Responses. Journal of Veterinary Advances, 4, 732-745. https://doi.org/10.5455/jva.20141129012406

[119] Ouma, J.O., Olaho-Mukani, W., Wishitemi, B. and Guya, S. (1997) Changes in Classical Pathway Complement Activity in Dromedary Camels Experimentally Infected with Trypanosoma Evansi. Veterinary Immunology and Immunopathology, 57, 135-140. https://doi.org/10.1016/S0165-2427(96)05758-3

[120] Desquesnes, M., Holzmuller, P., Lai, D.-H., Dargantes, A., Lun, Z.-R. and Jittaplapong, S. (2013) Trypanosoma Evansi and Surra: A Review and Perspectives on Origin, History, Distribution, Taxonomy, Morphology, Hosts, and Pathogenic Effects. BioMed Research International, 2013, Article ID: 194176.

https://doi.org/10.1155/2013/194176

[121] Boid, R., Hunter, A., Jones, T., Ross, C., Sutherland, D. and Luckins, A. (1996) Trypanosomosis Research at the Centre for Tropical Veterinary Medicine (Ctvm) 1970 to 1995. Tropical Animal Health and Production, 28, 5-22. https://doi.org/10.1007/BF02250724

[122] Zewdu, A., Negash, A., Assen, A., Yaregal, B. and Gondar, E. (2016) Camel Trypanosomosis: A Review on Diagnostic Approaches and Immunological Consequences. Journal of Pharmacy and Alternative Medicine, 10, 64-71.

[123] Al Dahouk, S. and Nöckler, K. (2011) Implications of Laboratory Diagnosis on Brucellosis Therapy. Expert Review of Anti-Infective Therapy, 9, 833-845. https://doi.org/10.1586/eri.11.55

[124] Bosilkovski, M. (2015) Brucellosis: It Is Not Only Malta! In: Zoonoses-Infections Affecting Humans and Animals, Springer, Berlin, 287-315. https://doi.org/10.1007/978-94-017-9457-2_11

[125] Chinyoka, S., Dhliwayo, S., Marabini, L., Dutlow, K., Matope, G. and Pfukenyi, D.M. (2014) Serological Survey of Brucella canis in Dogs in Urban Harare and Selected Rural Communities in Zimbabwe. Journal of the South African Veterinary Association, 85, e1-e5. https://doi.org/10.4102/jsava.v85i1.1087 
[126] Bryne, D. (2002) Commission Regulation (Ec) No. 535/2002 of 21 March 2002 Amending Annex C to Council Directive 64/432/Eec and Amending Decision 2000/330/Ec. Official Journal of the European Communities L, 80, 1-7.

[127] Doosti, A., Ahmadi, R. and Arshi, A. (2012) Pcr Detection of Leptospirosis in Iranian Camels. Bulgarian Journal of Veterinary Medicine, 15, 178-183.

[128] Hussein, M.F. and El-Nabi, A.G. (2009) Serological Evidence of Leptospirosis in Camels in Saudi Arabia. Journal of Animal and Veterinary Advances, 8, 1010-1012. https://doi.org/10.3923/javaa.2009.1010.1012

[129] Niloofa, R., Fernando, N., de Silva, N.L., Karunanayake, L., Wickramasinghe, H., Dikmadugoda, N., Premawansa, G., Wickramasinghe, R., de Silva, H.J. and Premawansa, S. (2015) Diagnosis of Leptospirosis: Comparison between Microscopic Agglutination Test, Igm-Elisa and Igm Rapid Immunochromatography Test. PLoS ONE, 10, e0129236. https://doi.org/10.1371/journal.pone.0129236

[130] Dubey, J. (1997) Validation of the Specificity of the Modified Agglutination Test for Toxoplasmosis in Pigs. Veterinary Parasitology, 71, 307-310.

https://doi.org/10.1016/S0304-4017(97)00016-2

[131] Shaapan, R., El-Nawawi, F. and Tawfik, M. (2008) Sensitivity and Specificity of Various Serological Tests for the Detection of Toxoplasma gondii Infection in Naturally Infected Sheep. Veterinary Parasitology, 153, 359-362.

https://doi.org/10.1016/j.vetpar.2008.02.016

[132] Wong, C.L., Yong, C.Y., Ong, H.K., Ho, K.L. and Tan, W.S. (2020) Advances in the Diagnosis of Foot-and-Mouth Disease. Frontiers in Veterinary Science, 7, 477.

https://doi.org/10.3389/fvets.2020.00477

[133] Serhan, W.S., Khan, R.A., Gasim, E.F., Alketbi, M.S., De Massis, F., Calistri, P., Giovannini, A., Al Hosani, M.A., Al Jaberi, S.A. and Al Mansoori, A.M. (2019) Performance of an Immunochromatographic Test (Ict) in Comparison to Some Commonly Used Serological Tests for the Diagnosis of Brucellosis in Dromedary Camels (Camelus dromedarius). Microorganisms, 7, 591. https://doi.org/10.3390/microorganisms7120591

[134] Khan, A.U., Sayour, A.E., Melzer, F., El-Soally, S.A.G.E., Elschner, M.C., Shell, W.S., Moawad, A.A., Mohamed, S.A., Hendam, A. and Roesler, U. (2020) Seroprevalence and Molecular Identification of Brucella Spp. in Camels in Egypt. Microorganisms, 8, 1035. https://doi.org/10.3390/microorganisms8071035

[135] Lee, C. (2007) Western Blotting. In: R, E., Ed., Circadian Rhythms. Methods in Molecular Biology ${ }^{\tau \mu}$, Humana Press, Totowa, 391-399. https://doi.org/10.1007/978-1-59745-257-1_30

[136] Kim, J.-Y., Sung, S.-R., Lee, K., Lee, H.-K., Kang, S.-I., Lee, J.J., Jung, S.C., Park, Y.H. and Her, M. (2014) Immunoproteomics of Brucella Abortus Rb51 as Candidate Antigens in Serological Diagnosis of Brucellosis. Veterinary Immunology and Immunopathology, 160, 218-224. https://doi.org/10.1016/j.vetimm.2014.05.009

[137] Nielsen, K., Cherwonogrodzky, J., Duncan, J. and Bundle, D. (1989) Enzyme-Linked Immunosorbent Assay for Differentiation of the Antibody Response of Cattle Naturally Infected with Brucella Abortus or Vaccinated with Strain 19. American Journal of Veterinary Research, 50, 5-9.

[138] Karim, R. (2018) Elisa: History, Types and Applications Medical Procedures, Testing and Technology. Nova Science Publishers, Incorporated, Hauppauge.

[139] Intisar, K., Ali, Y., Khalafalla, A., Taha, K. and Rahman, M.E. (2010) Adenovirus Type 3 Infections in Camels in Sudan. African Journal of Microbiology Research, 4, 1356-1358. 
[140] Samkange, A., Katsande, T.C., Tjipura-Zaire, G. and Crafford, J.E. (2010) Seroprevalence Survey of Chlamydophila Abortus Infection in Breeding Goats on Commercial Farms in the Otavi Veterinary District, Northern Namibia. Onderstepoort Journal of Veterinary Research, 77, E1-E5. https://doi.org/10.4102/ojvr.v77i1.1

[141] Azwai, S., Carter, S., Woldehiwet, Z. and Wernery, U. (1996) Serology of Orthopoxvirus Cameli Infection in Dromedary Camels: Analysis by Elisa and Western Blotting. Comparative Immunology, Microbiology and Infectious Diseases, 19, 65-78. https://doi.org/10.1016/0147-9571(95)00023-2

[142] Aljasim, T.A., Almasoud, A., Aljami, H.A., Alenazi, M.W., Alsagaby, S.A., Alsaleh, A.N. and Alharbi, N.K. (2020) High Rate of Circulating Mers-Cov in Dromedary Camels at Slaughterhouses in Riyadh, 2019. Viruses, 12, 1215.

https://doi.org/10.3390/v12111215 